\title{
Synthetic and reactivity studies of mono- and dicyclopentadienyl titanium, zirconium and hafnium complexes with the chlorodimethylsilyl-cyclopentadienyl ligand. X-ray molecular structure of $\mathrm{Hf}\left\{\left(\eta^{5}-\mathrm{C}_{5} \mathrm{H}_{4}\right) \mathrm{SiMe}_{2} \mathrm{OSiMe}_{2}\left(\eta^{5}-\mathrm{C}_{5} \mathrm{H}_{4}\right)\right\} \mathrm{Cl}_{2}$ and $\mathrm{Zr}\left(\eta^{5}-1,3-{ }^{t} \mathrm{Bu}_{2} \mathrm{C}_{5} \mathrm{H}_{3}\right)\left(\eta^{5}-\mathrm{C}_{5} \mathrm{H}_{4} \mathrm{SiMe}_{2}-\eta-\mathrm{N}^{t} \mathrm{Bu}\right) \mathrm{Cl}$
}

\author{
Santiago Ciruelos, Alfredo Sebastián, Tomás Cuenca, Pilar Gómez-Sal ${ }^{1}$, \\ Antonio Manzanero ${ }^{1}$, Pascual Royo * \\ Departamento de Química Inorgánica, Universidad de Alcalá, Campus Universitario, 28871 Alcalá de Henares, Spain
}

Received 9 February 2000; accepted 5 April 2000

\begin{abstract}
Reaction of the disilylated cyclopentadiene $\mathrm{C}_{5} \mathrm{H}_{4}\left(\mathrm{SiClMe}_{2}\right)\left(\mathrm{SiMe}_{3}\right)$ with $\mathrm{HfCl}_{4}$, in heptane, gave the monocyclopentadienyl complex $\mathrm{Hf}\left(\eta^{5}-\mathrm{C}_{5} \mathrm{H}_{4} \mathrm{SiClMe}_{2}\right) \mathrm{Cl}_{3}$ (1c). Addition of two equivalents of $\mathrm{C}_{5} \mathrm{H}_{5}\left(\mathrm{SiClMe}_{2}\right)$ to a solution of $\mathrm{MCl}_{4}$, in toluene under reflux and in the presence of two equivalents of $\mathrm{NEt}_{3}$, afforded the dichloro derivatives $\mathrm{M}\left(\eta^{5}-\mathrm{C}_{5} \mathrm{H}_{4} \mathrm{SiClMe}_{2}\right)_{2} \mathrm{Cl}_{2}[\mathrm{M}=\mathrm{Ti}(\mathbf{2 a}), \mathrm{Hf}$ (2c)]. Compounds $\mathbf{2 a}$ and $\mathbf{2 c}$ react with a stoichiometric amount of water with selective hydrolysis of the $\mathrm{Si}-\mathrm{Cl}$ bonds to give the tetramethyldisiloxane-bridged diciclopentadienyl complexes $\mathrm{M}\left\{\left(\eta^{5}-\mathrm{C}_{5} \mathrm{H}_{4}\right) \mathrm{SiMe}_{2} \mathrm{OSiMe}_{2}\left(\eta^{5}-\mathrm{C}_{5} \mathrm{H}_{4}\right)\right\} \mathrm{Cl}_{2}[\mathrm{M}=\mathrm{Ti}$ (3a), $\mathrm{Hf}$ (3c)]. The reaction of the trichloro metal compounds $\mathrm{M}\left(\eta^{5}-\mathrm{C}_{5} \mathrm{H}_{4} \mathrm{SiClMe}_{2}\right) \mathrm{Cl}_{3}$ with $\mathrm{Tl}\left(1,3-{ }^{t} \mathrm{Bu}_{2} \mathrm{C}_{5} \mathrm{H}_{3}\right), \mathrm{K}\left(\mathrm{C}_{5} \mathrm{Me}_{5}\right)$ or $\mathrm{Tl}\left(\mathrm{C}_{5} \mathrm{H}_{5}\right)$ afforded the dichloro mixed dicyclopentadienyl $\mathrm{MCp}^{\prime}\left(\eta^{5}-\mathrm{C}_{5} \mathrm{H}_{4} \mathrm{SiClMe}_{2}\right) \mathrm{Cl}_{2}$ derivatives $\left[\mathrm{Cp}^{\prime}=1,3-{ }^{t} \mathrm{Bu}_{2} \mathrm{C}_{5} \mathrm{H}_{3}, \mathrm{M}=\mathrm{Ti}(\mathbf{4 a}), \mathrm{Zr}(\mathbf{4 b})\right.$, $\mathrm{Hf}(\mathbf{4 c})$; $\mathrm{Cp}^{\prime}=\mathrm{C}_{5} \mathrm{Me}_{5}, \mathrm{M}=\mathrm{Zr}(\mathbf{5 b})$, Hf (5c); $\left.\mathrm{Cp}^{\prime}=\mathrm{C}_{5} \mathrm{H}_{5}, \mathrm{M}=\mathrm{Hf}(\mathbf{6 c})\right]$. The $\mathrm{Si}-\mathrm{Cl}$ bond of the mixed dicyclopentadienyl complexes $\mathrm{M}\left(\eta^{5}-1,3-{ }^{t} \mathrm{Bu}_{2} \mathrm{C}_{5} \mathrm{H}_{3}\right)\left(\eta^{5}-\mathrm{C}_{5} \mathrm{H}_{4} \mathrm{SiClMe}_{2}\right) \mathrm{Cl}_{2}$, [M = Ti (4a), $\mathrm{Zr}(\mathbf{4 b})$, Hf (4c)] reacts selectively with one equivalent of $\mathrm{LiNH}^{t} \mathrm{Bu}$ in toluene at $50-60^{\circ} \mathrm{C}$ to give the amidosilyl(cyclopentadienyl) compounds $\mathrm{M}\left(\eta^{5}-1,3-{ }^{t} \mathrm{Bu}_{2} \mathrm{C}_{5} \mathrm{H}_{3}\right)\left(\eta^{5}-\mathrm{C}_{5} \mathrm{H}_{4} \mathrm{SiMe}_{2} \mathrm{NH}^{t} \mathrm{Bu}\right) \mathrm{Cl}_{2},[\mathrm{M}=\mathrm{Ti}$ (7a), $\mathrm{Zr}(\mathbf{7 b}), \mathrm{Hf}(\mathbf{7 c})]$. The same reaction with two equivalents of the lithium amide gives the ansa-cyclopentadienylsilyl-amido compounds $\mathrm{M}\left(\eta^{5}-1,3-{ }^{t} \mathrm{Bu}_{2} \mathrm{C}_{5} \mathrm{H}_{3}\right)\left(\eta^{5}-\mathrm{C}_{5} \mathrm{H}_{4} \mathrm{SiMe}_{2}-\eta-\mathrm{N}^{t} \mathrm{Bu}\right) \mathrm{Cl}[\mathrm{M}=\mathrm{Ti}(\mathbf{8 a}), \mathrm{Zr}(\mathbf{8 b})$, Hf $(\mathbf{8 c})]$. The X-ray molecular structure of $\operatorname{Hf}\left\{\left(\eta^{5}-\mathrm{C}_{5} \mathrm{H}_{4}\right) \mathrm{SiMe}_{2} \mathrm{OSiMe}_{2}\left(\eta^{5}-\mathrm{C}_{5} \mathrm{H}_{4}\right)\right\} \mathrm{Cl}_{2}(\mathbf{3 c})$ and $\mathrm{Zr}\left(\eta^{5}-1,3-{ }^{t} \mathrm{Bu}_{2} \mathrm{C}_{5} \mathrm{H}_{3}\right)\left(\eta^{5}-\mathrm{C}_{5} \mathrm{H}_{4} \mathrm{SiMe}_{2}-\eta-\mathrm{N}^{t} \mathrm{Bu}\right) \mathrm{Cl}(\mathbf{8 b})$ have been determined by diffraction methods. (C) 2000 Elsevier Science S.A. All rights reserved.
\end{abstract}

\section{Keywords: Titanium; Zirconium; Hafnium; Chlorodimethylsilyl-cyclopentadienyl; Mixed dicyclopentadienyl; Amido cyclopentadienyl}

\section{Introduction}

Metallocene complexes of Group 4 metals have been the subject of considerable interest for many years due to their synthetic and catalytic applications [1]. Extensive studies on the applications of Group 4 dicyclopentadienyl derivatives, as homogeneous $\alpha$-olefin polymerization catalysts have been reported [2]. More recently, these studies have been extended to the use of substituted cyclopentadienyl ligands which contain link-

\footnotetext{
* Corresponding author. Fax: + 34-1-8854683.

${ }^{1} \mathrm{X}$-ray diffraction studies.
}

ing groups that can modify the steric and electronic properties of the metal centre [3]. An important class of such compounds is those formed by bidentate ligands derived from a cyclopentadienyl ring functionalized with a pendant neutral or anionic functionality. Several complexes with nitrogen [4] and oxygen [5] functionalized cyclopentadienyl ligands containing an olefin in the cyclopentadienyl substituent [6] are known and they have opened up an interesting and rapidly growing field in the organometallic chemistry of these metals.

Some of these new systems show promising possibilities for the design of well-defined organometallic compounds with selective catalytic activity. Specifically, the 
so-called ansa-monocyclopentadienyl-amido or half sandwich metallocenes of 'constrained geometry' (CGC) are highly active systems to produce $\alpha$-olefin polymers and ethylene- $\alpha$-olefin copolymers with remarkable properties [7,8]. In previous papers we have reported the synthesis and reactivity of mono- and dicyclopentadienyl complexes of titanium and zirconium containing the chlorodimethylsilylcyclopentadienyl ring [9], and we have developed a new approach to the synthesis of cyclopentadienyl-amido precursors by reactions of these suitable starting materials with different lithium amides or primary amines [10]. This strategy is very efficient for titanium compounds and appears to be a good way to synthesise cyclopentadienyl-amido precursors with unsubstituted cyclopentadieny ligands.

In this paper we report on the isolation of new mono- and mixed di-cyclopentadienyl Group 4 metal complexes containing chlorodimethyl-substituted rings and their reactions with lithium amides to afford novel cyclopentadienylsilyl-amido complexes.

\section{Results and discussion}

\subsection{Mono- and di-(chlorodimethylsilyl- cyclopentadienyl) complexes}

The same reaction of the disilylated cyclopentadiene $\mathrm{C}_{5} \mathrm{H}_{4}\left(\mathrm{SiClMe}_{2}\right)\left(\mathrm{SiMe}_{3}\right)$ reported previously for titanium and zirconium [9a] was carried out using $\mathrm{HfCl}_{4}$ in heptane to give the monocyclopentadienyl derivative $\mathrm{Hf}\left(\eta^{5}-\mathrm{C}_{5} \mathrm{H}_{4} \mathrm{SiClMe}_{2}\right) \mathrm{Cl}_{3}$ (1c) in $56 \%$ yield (Scheme 1). The solvent appears to be crucial because the same reaction in toluene produces a black oil from which pure samples of $\mathbf{1 c}$ could be isolated in only very low yields.

Several routes have been reported [1b] to coordinate two cyclopentadienyl ligands to a transition metal centre. For Group 4 metals, the most common is the salt metathesis reaction of an alkali-metal cyclopentadienyl compound with the corresponding metal halide $\mathrm{MCl}_{4}$ $(\mathrm{M}=\mathrm{Ti}, \mathrm{Zr}, \mathrm{Hf})$. However the synthesis of a stable salt of the $\left(\mathrm{C}_{5} \mathrm{H}_{4} \mathrm{SiClMe}_{2}\right)^{-}$anion has serious limitations. The salts $\mathrm{M}^{\prime}\left(\mathrm{C}_{5} \mathrm{H}_{4} \mathrm{SiClMe}_{2}\right)\left(\mathrm{M}^{\prime}=\right.$ alkali metal or $\left.\mathrm{Tl}\right)$ resulting from deprotonation of $\mathrm{C}_{5} \mathrm{H}_{5}\left(\mathrm{SiClMe}_{2}\right)$ with basic reagents such as $\mathrm{M}^{\prime} \mathrm{R}$ or TlOEt are unstable and eliminate the alkali or thallium halide easily to give

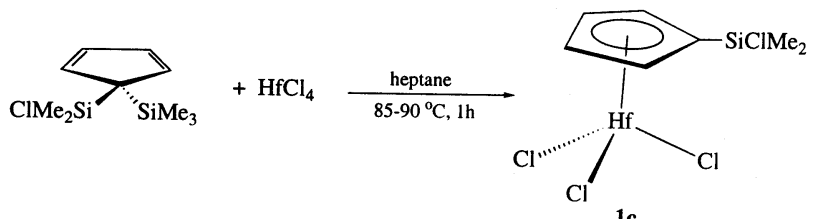

$\underline{1 c}$ silylene intermediates [11]. A new and elegant way, introduced recently in the literature, is the reaction of homoleptic metal amides $\mathrm{M}\left(\mathrm{NR}_{2}\right)_{4}$ with the cyclopentadiene ligand to produce the dicyclopentadienyl diamido compounds via amine elimination. The subsequent reaction with $\mathrm{SiClMe}_{3}$ yields the corresponding dichlorides [12]. The reaction of $\mathrm{M}\left(\mathrm{NR}_{2}\right)_{4}(\mathrm{M}=\mathrm{Ti}, \mathrm{Zr}, \mathrm{Hf})$ with the $\mathrm{C}_{5} \mathrm{H}_{5}\left(\mathrm{SiClMe}_{2}\right)$ ligand gave a mixture of products which could not be characterised conclusively. Exchanges between the dialkylamido groups and the $\mathrm{SiClMe}_{2}$ functionality of the ring have been observed. A clean and salt free route to synthesise compounds of this type is the reaction of trimethylsilyl-cyclopentadiene reagents with $\mathrm{MCl}_{4}$ resulting in the elimination of two equivalents of $\mathrm{SiClMe}_{3}$ which can be pumped off easily [13]. We have reported that this strategy works out very well for the synthesis of dicyclopentadienyl zirconium derivatives and the dicyclopentadienyl compound $\mathrm{Zr}\left(\eta^{5}-\mathrm{C}_{5} \mathrm{H}_{4} \mathrm{SiClMe}\right)_{2} \mathrm{Cl}_{2}$ was obtained in $74 \%$ yield [9a]. However the related dicyclopentadienyl titanium and hafnium complexes could not be synthesised in this way. The reaction with $\mathrm{TiCl}_{4}$ affords the monocyclopentadienyl compound $\mathrm{Ti}\left(\eta^{5}-\mathrm{C}_{5} \mathrm{H}_{4} \mathrm{SiClMe}_{2}\right) \mathrm{Cl}_{3}$ and $\mathrm{HfCl}_{4}$ produces a mixture of the mono- (1c) and dicyclopentadienyl (2c) derivatives.

An alternative method to coordinate the cyclopentadienyl ring to the metal centre is based in the deprotonation of the precursor cyclopentadiene acidic hydrogen with $\mathrm{NEt}_{3}$ in the presence of metal halides [1b]. When a toluene solution of $\mathrm{TiCl}_{4}$ was treated with two equivalents of $\mathrm{C}_{5} \mathrm{H}_{5}\left(\mathrm{SiClMe}_{2}\right)$ in the presence of two equivalents of $\mathrm{NEt}_{3}$, a dark solution was obtained which after refluxing for $3 \mathrm{~h}$ gave the new $\operatorname{Ti}\left(\eta^{5}\right.$ $\left.\mathrm{C}_{5} \mathrm{H}_{4} \mathrm{SiClMe}_{2}\right)_{2} \mathrm{Cl}_{2}$ (2a) complex in $43 \%$ yield (Scheme 2). This result contrasts with that found when the same reaction was carried out with $\mathrm{C}_{5} \mathrm{H}_{6}$, where $\mathrm{Ti}\left(\eta^{5}\right.$ $\left.\mathrm{C}_{5} \mathrm{H}_{5}\right)_{2} \mathrm{Cl}_{2}$ was obtained in a $3 \%$ yield only. The difference could be explained by the higher acidity of the hydrogen bound to the $\mathrm{SiClMe}_{2}$-substituted $\mathrm{sp}^{3}$ carbon atom of the ciclopentadiene $\mathrm{C}_{5} \mathrm{H}_{5}\left(\mathrm{SiClMe}_{2}\right)$, promoted by the presence of chlorine in the $\mathrm{SiClMe}_{2}$ substituent. Using this method, the known zirconium [9a] and the new hafnium $\mathrm{Hf}\left(\eta^{5}-\mathrm{C}_{5} \mathrm{H}_{4} \mathrm{SiClMe}_{2}\right)_{2} \mathrm{Cl}_{2}$ (2c) complexes were also obtained in moderate yields.

Complexes 1 and $\mathbf{2}$ show the characteristic thermal stability of Group 4 mono- and dicyclopentadienyl derivatives but are moisture sensitive due to the ease of hydrolysis at the $\mathrm{Si}-\mathrm{Cl}$ bond. They are insoluble in hydrocarbons and soluble in toluene and chlorinated solvents.

Compounds $\mathbf{2 a}$ and $\mathbf{2 c}$ react with a stoichiometric amount of water with selective hydrolysis of the $\mathrm{Si}-\mathrm{Cl}$ bonds to give the corresponding tetramethyldisiloxanebridged diciclopentadienyl complexes $\mathrm{M}\left\{\left(\eta^{5}-\right.\right.$ $\left.\left.\mathrm{C}_{5} \mathrm{H}_{4}\right) \mathrm{SiMe}_{2} \mathrm{OSiMe}_{2}\left(\eta^{5}-\mathrm{C}_{5} \mathrm{H}_{4}\right)\right\} \mathrm{Cl}_{2} \quad$ (3a) and (3c), respectively, similar to the behaviour reported previously for the analogous zirconium derivative [9a]. The 


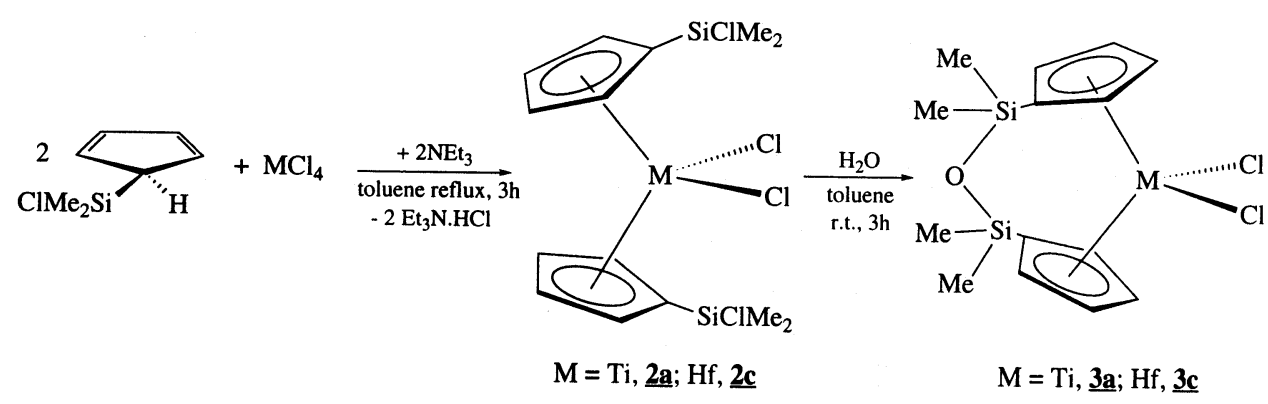

Scheme 2 .

preparation of 3a was reported earlier by a reaction of the $\mathrm{Na}_{2}\left[\left(\mathrm{C}_{5} \mathrm{H}_{4} \mathrm{SiMe}_{2}\right)(\mu-\mathrm{O})\right]$ salt with $\mathrm{TiCl}_{4} \cdot 2$ py [14].

The ${ }^{1} \mathrm{H}-\mathrm{NMR}\left(\mathrm{C}_{6} \mathrm{D}_{6}\right.$ and $\left.\mathrm{CDCl}_{3}\right)$ spectra for the new complexes 1-3 show the presence of one singlet for the methyl-silyl protons and two pseudotriplets corresponding to an $\mathrm{AA}^{\prime} \mathrm{BB}^{\prime}$ spin system for the cyclopentadienyl protons $[9 b, 15]$. Three resonances assigned to the distal, proximal and $\mathrm{C}_{i p s o}$ carbon atoms of the cyclopentadienyl ring and one resonance for the $\mathrm{SiMe}_{2}$ group are found in the ${ }^{13} \mathrm{C}$-NMR spectra of these complexes. The chemical shift of the $\mathrm{C}_{i p s o}$ atom being typically shifted upfield in comparison with the average shift observed for the other $\mathrm{C}_{5} \mathrm{H}_{4}$ ring carbon resonances for complexes 3a and $\mathbf{3 c}$, and shifted downfield in comparison with those for compounds 1c, 2a and 2c [9]. The value of $\Delta \delta=\delta_{\mathrm{d}}-\delta_{\mathrm{p}}\left(\delta_{\mathrm{d}}\right.$ and $\delta_{\mathrm{p}}$ being the chemical shifts of the distal and proximal protons of the cyclopentadienyl rings with respect to the silicon atom) and the relative chemical shifts of the bridgehead carbon $\left(\mathrm{C}_{i p s o}\right)$ of the cyclopentadienyl rings, found in the NMR spectra for these complexes, have been used as characteristic spectroscopic parameters to define the coordination modes of the silyl-substituented cyclopentadienyl ligands [9b]. It has been observed that in chelated compounds, the $\mathrm{C}_{i p s o}$ resonance appeared at higher fields than the proximal and distal carbon resonances of the same ring, while for bridged dinuclear derivatives or for unbridged mononuclear substituted metallocene analogues, the reverse was observed. This feature has been explained as the result of a redistribution of the $\pi$-electron density of the ring caused by the presence of the silicon atom [9b], as observed for compounds $\mathbf{1 - 3}$, whereas the $\Delta \delta$ parameter is less useful.

Unlike the structure observed in the solid (see below), the ${ }^{1} \mathrm{H}-\mathrm{NMR}$ spectra of $\mathbf{3 a}$ and $\mathbf{3 c}$ show (even at $-78^{\circ} \mathrm{C}$ ) a symmetrical $\mathrm{AA}^{\prime} \mathrm{BB}^{\prime}$ pattern for the cyclopentadienyl protons of both rings and one singlet for the silicon methyl protons, indicating that in solution, the cyclopentadienyl bridging siloxy groups twist to give a $C_{2}$ symmetric intermediate.

Single crystals of 3c suitable for X-ray diffraction were obtained by slow cooling of toluene-hexane solutions. The molecular structure of compound $\mathbf{3 c}$ is shown in Fig. 1 with the atom-labelling scheme. Selected bond distances and bond angles are listed in Table 1.

The molecular structure corresponds to a typical pseudotetrahedral molecule, the four ligands being the ring centroids and the chlorine atoms. The two cyclopentadienyl rings are bonded by the $\mathrm{Si}-\mathrm{O}-\mathrm{Si}$ chain and the molecule shows structural features comparable with those reported previously for the similar titanium and zirconium derivatives. A structural comparison of 3c with the related tetramethyldisiloxane-bridged dicyclopentadienyl $\mathrm{M}\left\{\left(\eta^{5}-\mathrm{C}_{5} \mathrm{H}_{4}\right) \mathrm{SiMe}_{2} \mathrm{OSiMe}_{2}\left(\eta^{5}-\mathrm{C}_{5} \mathrm{H}_{4}\right)\right\}$ $\mathrm{Cl}_{2}$ titanium [14] and zirconium [9a] complexes is shown in Table 2 and points out that the isostructural zirconium and hafnium organometallic compounds show very similar bond distances which are slightly shorter $(0.01-0.02 \AA)$ for the hafnium compound, whereas they are longer for the titanium compound with differences expected for early $3 \mathrm{~d}-5 \mathrm{~d}$ transition metals [1].

The oxygen atom is slightly out $[0.049(3) \AA]$ of the reflection plane defined by the hafnium and chlorine atoms. Both rings are located in an eclipsed disposition. The $\mathrm{Si}-\mathrm{O}-\mathrm{Si}$ bond angle of $142.3(3)^{\circ}$, and the $\mathrm{Si}-\mathrm{O}$ bond distances [1.633(4) and 1.642(4) $\AA$ ] are similar to those observed in hexamethyldisiloxane [16]. The $\mathrm{Si}-\mathrm{O}-\mathrm{Si}$ bridge is not symmetrically oriented with respect to the $\mathrm{Cl}-\mathrm{Hf}-\mathrm{Cl}$ angle causing a wedging of the ring. Because of this disposition, the minimum $\mathrm{C}-\mathrm{C}$ bond distance between the rings corresponds to the proximal carbon atoms $[\mathrm{C}(25)-\mathrm{C}(15)]$, being shorter than the $\mathrm{C}_{i p s o}-\mathrm{C}_{i p s o}[\mathrm{C}(11)-\mathrm{C}(21)]$ distance. The angle between the $\mathrm{Cp}$ planes $\left[50.5(2)^{\circ}\right]$ and the $\mathrm{Cp}$ (centroid)-Hf- $\mathrm{Cp}$ (centroid) angle in $3 \mathbf{c}\left(131.1^{\circ}\right)$ resembles those found in hafnocene dichlorides or other hafnocene substituted compounds [17]. The carbon-carbon bond distances within the two cyclopentadienyl rings are similar, ranging from 1.385(9) to $1.432(8) \AA$ and the same distances are also observed for the Hf-Cp(centroids) $(2.183$ and $2.192 \AA)$. The $\mathrm{Hf}-\mathrm{C}(\mathrm{Cp})$ distances, with a maximum difference of $0.082 \AA$, reveal $\eta^{5}$-coordination of both $\mathrm{Cp}$ rings. The $\mathrm{Hf}-\mathrm{Cl}$ distances $[\mathrm{Hf}-\mathrm{Cl}(1)$ 2.405(2) and $\mathrm{Hf}-\mathrm{Cl}(2)$ 
2.421(3) $\AA$ ] and the angle between the chlorine atoms of $97.54(8)^{\circ}$ are within the range expected for dichlorohafnocene derivatives (about $2.4 \AA$ ) [17]. However, the $\mathrm{Hf}-\mathrm{Cl}$ distances, in compound $\mathbf{3 c}$, show small differences $(0.016 \AA)$ due to the different effect of the siloxi group. A similar value for this difference has also been found for the analogous zirconium compound $(0.018 \AA$ ) but a significantly larger difference has been found for the titanium compound $(0.042 \AA)$. The longer bond corresponds to the chlorine atom located trans to the siloxy unit which bridges the two cyclopentadienyl rings. The $\mathrm{Si}-\mathrm{C}(\mathrm{Cp})$ distance average is $1.869 \AA$ and the $\mathrm{Si}-\mathrm{C}(\mathrm{Me})$ bond distances are in the range 1.834 (6)1.856 (8) A.

\subsection{Mixed dicyclopentadienyl complexes}

Mixed dicyclopentadienyl transition metal complexes are known [1,18] and many titanium and zirconium derivatives with the $\mathrm{C}_{5} \mathrm{H}_{5}$ or $\mathrm{C}_{5} \mathrm{H}_{4} \mathrm{SiMe}_{3}$ and $\mathrm{C}_{5} \mathrm{H}_{4} \mathrm{SiClMe}_{2}$ rings have been reported [9b].

The reaction of the trichloro metal compounds $\mathrm{M}\left(\eta^{5}\right.$ $\left.\mathrm{C}_{5} \mathrm{H}_{4} \mathrm{SiClMe}_{2}\right) \mathrm{Cl}_{3}[\mathrm{M}=\mathrm{Ti}, \mathrm{Zr}, \mathrm{Hf}(\mathbf{1 c})]$ with one equivalent of the thallium salt $\mathrm{Tl}\left(1,3-{ }^{t} \mathrm{Bu}_{2} \mathrm{C}_{5} \mathrm{H}_{3}\right)$ afforded the corresponding mixed dicyclopentadienyl derivatives $\mathrm{M}\left(\eta^{5}-1,3-{ }^{t} \mathrm{Bu}_{2} \mathrm{C}_{5} \mathrm{H}_{3}\right)\left(\eta^{5}-\mathrm{C}_{5} \mathrm{H}_{4} \mathrm{SiClMe}_{2}\right) \mathrm{Cl}_{2},[\mathrm{M}=\mathrm{Ti}(\mathbf{4 a})$, $\mathrm{Zr}(\mathbf{4 b})$, Hf (4c)] in high yield (60-75\%). Similarly, the compounds $\mathrm{M}\left(\eta^{5}-\mathrm{C}_{5} \mathrm{H}_{4} \mathrm{SiClMe}_{2}\right) \mathrm{Cl}_{3}[\mathrm{M}=\mathrm{Zr}$, Hf (1c)] react with $\mathrm{K}\left(\mathrm{C}_{5} \mathrm{Me}_{5}\right)$ or $\mathrm{Tl}\left(\mathrm{C}_{5} \mathrm{H}_{5}\right)$ to give the analogous mixed dicyclopentadienyl derivatives $\mathrm{M}\left(\eta^{5}-\mathrm{C}_{5} \mathrm{Me}_{5}\right)\left(\eta^{5}\right.$ $\left.\mathrm{C}_{5} \mathrm{H}_{4} \mathrm{SiClMe}_{2}\right) \mathrm{Cl}_{2}$, [M=Zr (5b), Hf (5c)] or $\mathrm{Hf}\left(\eta^{5}-\right.$ $\left.\mathrm{C}_{5} \mathrm{H}_{5}\right)\left(\eta^{5}-\mathrm{C}_{5} \mathrm{H}_{4} \mathrm{SiClMe}_{2}\right) \mathrm{Cl}_{2}$ (6) [9b] (Scheme 3).

Complexes 4-6 are insoluble in hydrocarbons and soluble in toluene and chlorinated solvents and show the characteristic thermal stability of Group 4 dicyclopentadienyl derivatives, being moisture sensitive due to the hydrolysis of the $\mathrm{SiClMe}_{2}$ unit.

The ${ }^{1} \mathrm{H}-\mathrm{NMR}$ spectra of complexes 4-6 $\left(\mathrm{C}_{6} \mathrm{D}_{6}\right.$ and $\mathrm{CDCl}_{3}$ ) show the expected resonances for the chlorodimethylsilyl cyclopentadienyl ring protons as two sets of pseudotriplets due to an $\mathrm{AA}^{\prime} \mathrm{BB}^{\prime}$ spin system $[9 \mathrm{~b}, 15]$. In the ${ }^{1} \mathrm{H}-\mathrm{NMR}$ spectra of complexes $\mathbf{4}$, the di(tert-butyl)cyclopentadienyl ring protons appear as one singlet for the tert-butyl protons and one $\mathrm{AA}^{\prime} \mathrm{B}$ spin system [one pseudo-doublet $(2 \mathrm{H})$ and one pseudo-triplet $(1 \mathrm{H})]$ for the cyclopentadienyl ring protons. Singlets for the $\mathrm{C}_{5} \mathrm{Me}_{5}$ and $\mathrm{C}_{5} \mathrm{H}_{5}$ protons are observed in the ${ }^{1} \mathrm{H}$ NMR spectra of compounds 5 and $\mathbf{6}$. For all of these compounds, in the ${ }^{13} \mathrm{C}-\mathrm{NMR}$ spectra, the resonance assigned to the $\mathrm{C}_{\text {ipso }}$ atom of the $\mathrm{C}_{5} \mathrm{H}_{4} \mathrm{SiClMe}_{2}$ ligand is shifted downfield with respect to the average shift for the other $\mathrm{C}_{5} \mathrm{H}_{4}$ ring carbon resonances [9].

\subsection{Reactions of the mixed dicyclopentadienyl complexes with lithium tert-butylamide}

Different methods have been used in order to find a convenient preparative route for ansa-monocyclopenta-

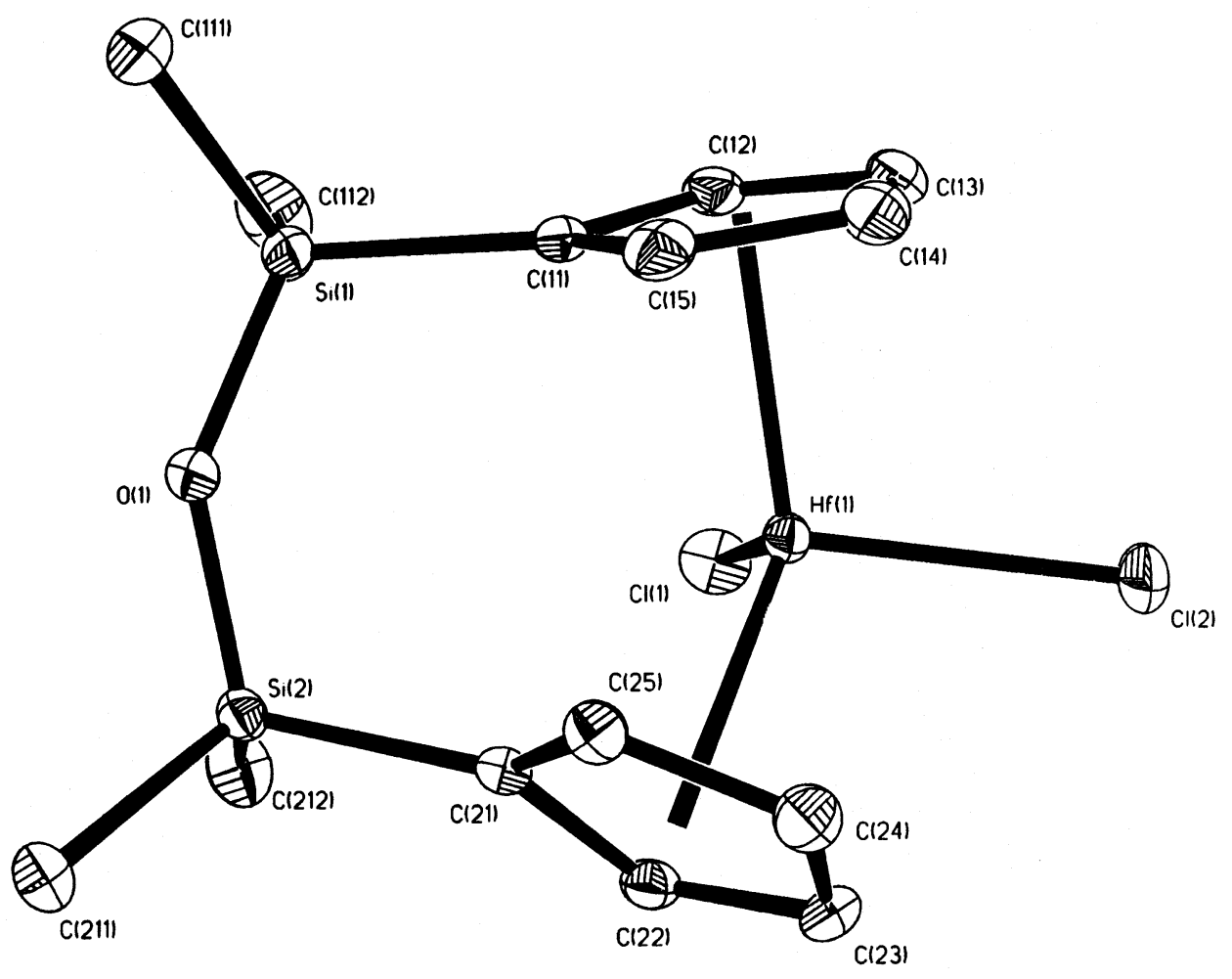

Fig. 1. ORTEP drawing view of the molecular structure of compound $3 \mathbf{c}$ together with the atomic labelling scheme 
Table 1

Selected bond distances $(\AA)$ and bond angles $\left({ }^{\circ}\right)$ for compound 3c

\begin{tabular}{|c|c|c|c|}
\hline \multicolumn{4}{|l|}{ Bond distances } \\
\hline $\mathrm{Hf}(1)-\mathrm{Cl}(1)$ & $2.405(2)$ & $\mathrm{Hf}(1)-\mathrm{Cl}(2)$ & $2.421(3)$ \\
\hline $\mathrm{Hf}(1)-\mathrm{Cp} 1$ & 2.192 & $\mathrm{Hf}(1)-\mathrm{Cp} 2$ & 2.183 \\
\hline $\mathrm{Hf}(1)-\mathrm{C}(11)$ & $2.483(5)$ & $\mathrm{Hf}(1)-\mathrm{C}(21)$ & $2.469(5)$ \\
\hline $\mathrm{Hf}(1)-\mathrm{C}(12)$ & $2.501(5)$ & $\mathrm{Hf}(1)-\mathrm{C}(22)$ & $2.500(5)$ \\
\hline $\mathrm{Hf}(1)-\mathrm{C}(13)$ & $2.513(6)$ & $\mathrm{Hf}(1)-\mathrm{C}(23)$ & $2.511(5)$ \\
\hline $\mathrm{Hf}(1)-\mathrm{C}(14)$ & $2.492(5)$ & $\mathrm{Hf}(1)-\mathrm{C}(24)$ & $2.488(5)$ \\
\hline $\mathrm{Hf}(1)-\mathrm{C}(15)$ & $2.493(5)$ & $\mathrm{Hf}(1)-\mathrm{C}(25)$ & $2.486(5)$ \\
\hline $\mathrm{Si}(1)-\mathrm{O}(1)$ & $1.633(4)$ & $\mathrm{Si}(2)-\mathrm{O}(1)$ & $1.642(4)$ \\
\hline $\mathrm{Si}(1)-\mathrm{C}(11)$ & $1.877(6)$ & $\mathrm{Si}(2)-\mathrm{C}(21)$ & $1.862(5)$ \\
\hline $\mathrm{Si}(1)-\mathrm{C}(111)$ & $1.856(8)$ & $\mathrm{Si}(2)-\mathrm{C}(211)$ & $1.834(6)$ \\
\hline $\mathrm{Si}(1)-\mathrm{C}(112)$ & $1.843(8)$ & $\mathrm{Si}(2)-\mathrm{C}(212)$ & $1.855(8)$ \\
\hline$C(13)-C(12)$ & $1.385(9)$ & $\mathrm{C}(22)-\mathrm{C}(23)$ & $1.388(8)$ \\
\hline$C(13)-C(14)$ & $1.401(10)$ & $C(24)-C(23)$ & $1.417(8)$ \\
\hline$C(15)-C(14)$ & $1.391(9)$ & $\mathrm{C}(25)-\mathrm{C}(24)$ & $1.396(8)$ \\
\hline$C(15)-C(11)$ & $1.412(8)$ & $C(21)-C(25)$ & $1.431(7)$ \\
\hline $\mathrm{C}(11)-\mathrm{C}(12)$ & $1.432(8)$ & $\mathrm{C}(21)-\mathrm{C}(22)$ & $1.425(7)$ \\
\hline \multicolumn{4}{|l|}{ Bond angles } \\
\hline $\mathrm{Cl}(1)-\mathrm{Hf}-\mathrm{Cl}(2)$ & $97.54(8)$ & $\mathrm{Cl}(1)-\mathrm{Hf}-\mathrm{Cp} 1$ & 106.3 \\
\hline $\mathrm{Cl}(2)-\mathrm{Hf}-\mathrm{Cpl}$ & 105.1 & $\mathrm{Cl}(1)-\mathrm{Hf}-\mathrm{Cp} 2$ & 106.8 \\
\hline $\mathrm{Cl}(2)-\mathrm{Hf}-\mathrm{Cp} 2$ & 105.1 & $\mathrm{Cp} 1-\mathrm{Hf}-\mathrm{Cp} 2$ & 131.1 \\
\hline $\mathrm{Si}(1)-\mathrm{O}(1)-\mathrm{Si}(2)$ & $142.3(3)$ & $\mathrm{O}(1)-\mathrm{Si}(1)-\mathrm{C}(112)$ & $110.8(3)$ \\
\hline $\mathrm{O}(1)-\mathrm{Si}(1)-\mathrm{C}(111)$ & $107.5(3)$ & $\mathrm{C}(112)-\mathrm{Si}(1)-\mathrm{C}(111)$ & $111.6(5)$ \\
\hline $\mathrm{O}(1)-\mathrm{Si}(1)-\mathrm{C}(11)$ & $110.4(2)$ & $\mathrm{C}(112)-\mathrm{Si}(1)-\mathrm{C}(11)$ & 109.2(3) \\
\hline $\mathrm{C}(111)-\mathrm{Si}(1)-\mathrm{C}(112)$ & $107.4(3)$ & $\mathrm{O}(1)-\mathrm{Si}(2)-\mathrm{C}(211)$ & $108.2(3)$ \\
\hline $\mathrm{O}(1)-\mathrm{Si}(2)-\mathrm{C}(112)$ & $111.4(3)$ & $\mathrm{C}(211)-\mathrm{Si}(2)-\mathrm{C}(212)$ & $110.8(3)$ \\
\hline $\mathrm{O}(1)-\mathrm{Si}(2)-\mathrm{C}(112)$ & $108.1(2)$ & $\mathrm{C}(211)-\mathrm{Si}(2)-\mathrm{C}(21)$ & $108.8(3)$ \\
\hline $\mathrm{C}(212)-\mathrm{Si}(2)-\mathrm{C}(21)$ & $109.5(3)$ & & \\
\hline
\end{tabular}

Table 2

Structural data for $\mathrm{M}\left\{\left(\eta^{5}-\mathrm{C}_{5} \mathrm{H}_{4}\right) \mathrm{SiMe}_{2} \mathrm{OSiMe}_{2}\left(\eta^{5}-\mathrm{C}_{5} \mathrm{H}_{4}\right)\right\} \mathrm{Cl}_{2}$ compounds $(\mathrm{M}=\mathrm{Ti}, \mathrm{Zr}$, Hf)

\begin{tabular}{llll}
\hline & $\mathrm{Ti}$ & $\mathrm{Zr}$ & $\mathrm{Hf}$ \\
\hline $\begin{array}{l}\text { Bond distances }(\stackrel{\mathrm{A}}{\mathrm{N}}) \\
\mathrm{M}-\mathrm{Cl}(1)\end{array}$ & & & \\
$\mathrm{M}-\mathrm{Cl}(2)$ & $2.381(1)$ & $2.4256(7)$ & $2.405(2)$ \\
$\mathrm{Si}(1)-\mathrm{O}$ & $2.339(1)$ & $2.4443(7)$ & $2.421(3)$ \\
$\mathrm{M}-\mathrm{Cp} 1^{\mathrm{a}}$ & $1.634(3)$ & $1.635(1)$ & $1.633(4)$ \\
$\mathrm{M}-\mathrm{Cp} 2$ & 2.065 & 2.202 & 2.192 \\
$\mathrm{Si}(2)-\mathrm{O}$ & 2.072 & 2.208 & 2.183 \\
Bond angles $\left(^{\circ}\right)$ & $1.630(3)$ & $1.627(2)$ & $1.642(4)$ \\
$\mathrm{Cl}(1)-\mathrm{M}-\mathrm{Cl}(2)$ & & & \\
$\mathrm{Cp} 1-\mathrm{M}-\mathrm{Cp} 2$ & $96.22(5)$ & $98.71(3)$ & $97.54(8)$ \\
$\mathrm{Si}(1)-\mathrm{O}-\mathrm{Si}(2)$ & 130.8 & 130.9 & 131.1 \\
$\mathrm{O}-\mathrm{Si}(1)-\mathrm{C}(1)$ & $141.5(2)$ & $143.5(1)$ & $142.3(3)$ \\
$\mathrm{O}-\mathrm{Si}(2)-\mathrm{C}(2)$ & $107.8(1)$ & $108.24(8)$ & 110.4 \\
\hline
\end{tabular}

\footnotetext{
${ }^{\text {a }} \mathrm{Cp}$ denotes ring centroids.
}

dienylsilyl-amido complexes. A possible method involves the reaction of $\mathrm{C}_{5} \mathrm{H}_{4}\left(\mathrm{SiClMe}_{2}\right)\left(\mathrm{SiMe}_{3}\right)$ with $\mathrm{MCl}_{4}$ to give $\mathrm{M}\left(\mathrm{C}_{5} \mathrm{H}_{4} \mathrm{SiClMe}_{2}\right) \mathrm{Cl}_{3} \quad(\mathrm{M}=$ Group 4 metal $)$ which subsequently reacts with LiNHR, in the presence of $\mathrm{NEt}_{3}$, to afford the corresponding ansa-monocyclopentadienyl-amido derivative [10].

When the mixed di(cyclopentadienyl) complexes $\mathrm{M}\left(\eta^{5}-1,3-{ }^{t} \mathrm{Bu}_{2} \mathrm{C}_{5} \mathrm{H}_{3}\right)\left(\eta^{5}-\mathrm{C}_{5} \mathrm{H}_{4} \mathrm{SiClMe}_{2}\right) \mathrm{Cl}_{2}, \quad[\mathrm{M}=\mathrm{Ti}$ (4a), $\mathrm{Zr}(\mathbf{4 b}), \mathrm{Hf}(\mathbf{4 c})]$ were treated with one equivalent of $\mathrm{LiNH}^{t} \mathrm{Bu}$ in toluene at $50-60^{\circ} \mathrm{C}$, the $\mathrm{Si}-\mathrm{Cl}$ bond reacted selectively to give the amidosilyl(cyclopentadienyl) compounds $\mathrm{M}\left(\eta^{5}-1,3-{ }^{t} \mathrm{Bu}_{2} \mathrm{C}_{5} \mathrm{H}_{3}\right)\left(\eta^{5}\right.$ $\left.\mathrm{C}_{5} \mathrm{H}_{4} \mathrm{SiMe}_{2} \mathrm{NH}^{t} \mathrm{Bu}\right) \mathrm{Cl}_{2},[\mathrm{M}=\mathrm{Ti}$ (7a), $\mathrm{Zr}$ (7b), Hf (7c)], obtained as red (titanium) or white (zirconium and hafnium) solids (Scheme 4). The desired ansa-cyclopentadienylsilyl-amido type derivatives $\mathbf{8}$ were not formed as expected from the known higher electrophilic character of the silicon atom in comparison with the transition metal centre in the dicyclopentadienyl-type derivatives. The related substituted cyclopentadienylsilyl-amido zirconium dichloride $\mathrm{Zr}\left(\eta^{5}-\mathrm{C}_{5} \mathrm{H}_{4} \mathrm{SiMe}_{2}-\right.$ $\left.\mathrm{NH}^{n} \mathrm{Bu}\right)_{2} \mathrm{Cl}_{2}$ complex has been reported [19] to be

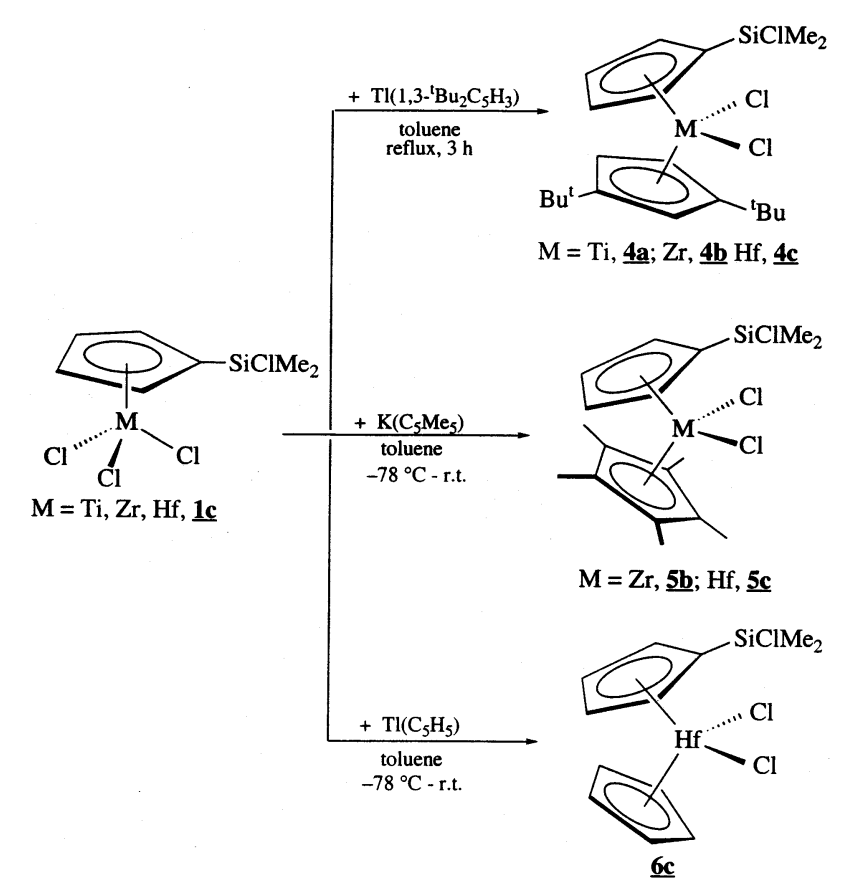

Scheme 3.

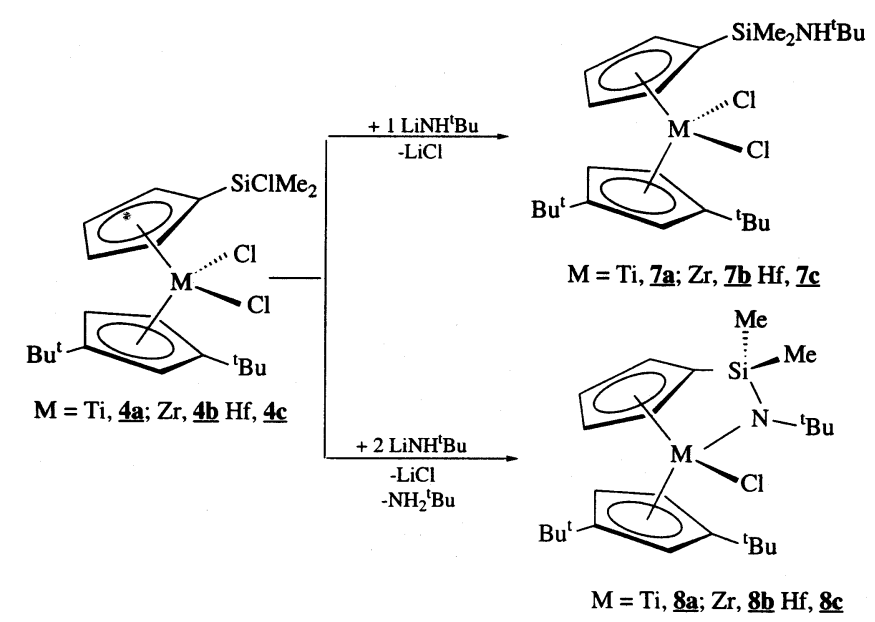

Scheme 4 . 


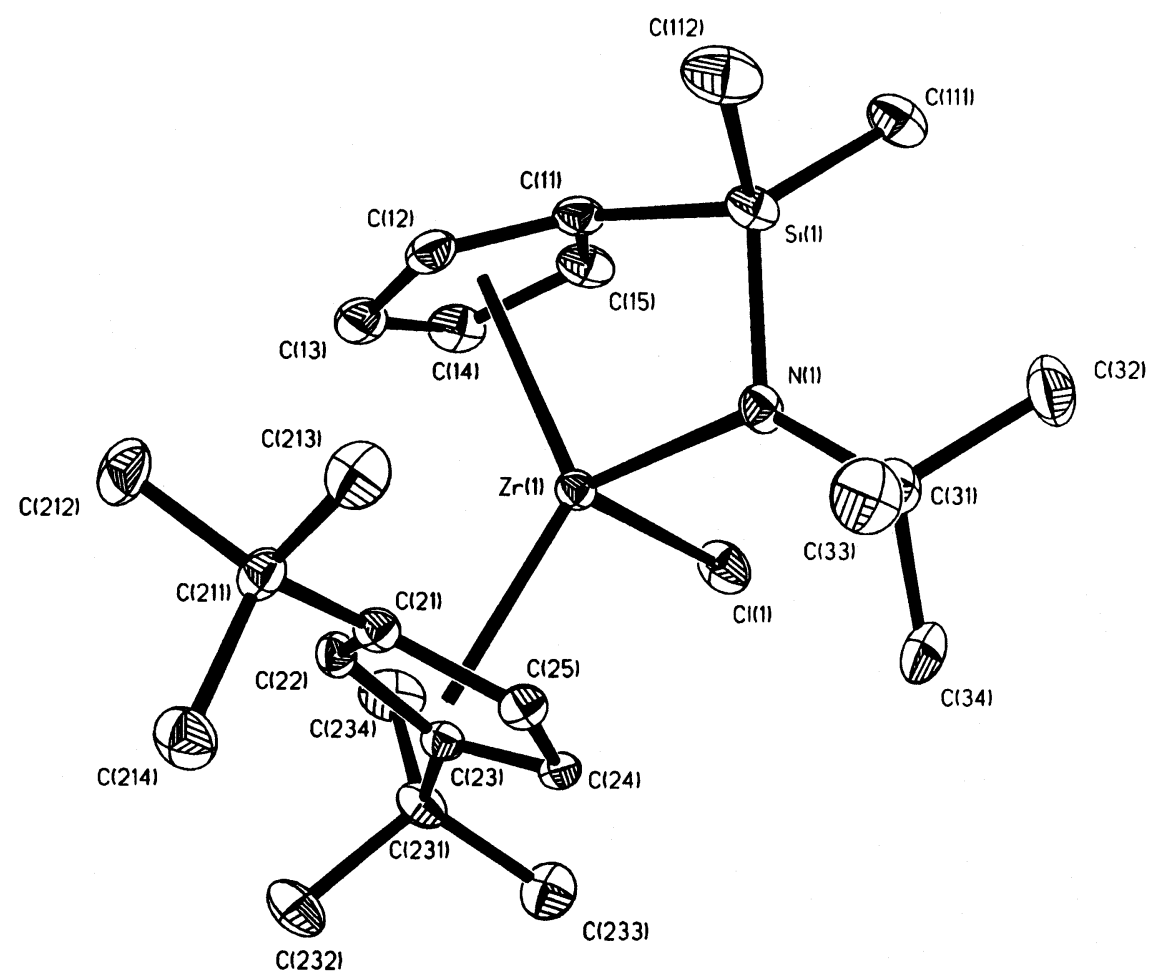

Fig. 2. ORTEP drawing view of the molecular structure of compound $\mathbf{8 b}$ together with the atomic labelling scheme

formed by reacting the lithium salt $\mathrm{Li}\left(\mathrm{C}_{5} \mathrm{H}_{4} \mathrm{SiMe}_{2}-\right.$ $\mathrm{NH}^{n} \mathrm{Bu}$ ) with a $1 / 2$ equivalent of $\mathrm{ZrCl}_{4}$.

However, when the same reaction was carried out using a metal-lithium amide molar ratio $1 / 2$, the ansacyclopentadienyl-amido red (titanium) and white (zirconium and hafnium) compounds $\mathrm{M}\left(\eta^{5}-1,3-{ }^{t} \mathrm{Bu}_{2} \mathrm{C}_{5^{-}}\right.$ $\left.\mathrm{H}_{3}\right)\left(\eta^{5}-\mathrm{C}_{5} \mathrm{H}_{4} \mathrm{SiMe}_{2}-\eta-\mathrm{N}^{t} \mathrm{Bu}\right) \mathrm{Cl}[\mathrm{M}=\mathrm{Ti}(\mathbf{8 a}), \mathrm{Zr}(\mathbf{8 b}), \mathrm{Hf}$ (8c)] were obtained in high yield $(80-90 \%)$ with the elimination of $\mathrm{LiCl}$ and the amine $\mathrm{NH}_{2}^{t} \mathrm{Bu}$ (Scheme 4).

The new compounds $\mathbf{7}$ and $\mathbf{8}$ are soluble in chlorinated solvents (chloroform and dichloromethane) as well as in aromatic hydrocarbons (benzene and toluene) and slightly soluble in hexane and pentane. They are air- and moisture-sensitive in solution and in the solid although they can be stored unaltered for weeks if strictly anaerobic conditions are maintained.

The ${ }^{1} \mathrm{H}-\mathrm{NMR}$ spectra $\left(\mathrm{C}_{6} \mathrm{D}_{6}\right.$ and $\left.\mathrm{CDCl}_{3}\right)$ of complexes 7 show the expected $\mathrm{AA}^{\prime} \mathrm{BB}^{\prime}$ spin system (two pseudotriplets) for the $\mathrm{C}_{5} \mathrm{H}_{4}$ ring protons, an $\mathrm{AA}^{\prime} \mathrm{B}$ spin system (two pseudotriplets) for the $\mathrm{C}_{5} \mathrm{H}_{3}$ ring protons, one singlet for the $\mathrm{SiMe}_{2}$ group, and two singlets for the tert-butyl $\mathrm{Cp}$ protons which are shifted down field with respect to the resonance assigned to the ${ }^{t} \mathrm{Bu}-\mathrm{N}$ group, the amidosilyl NH proton was not observed [19]. Compounds 8 show a chiral titanium centre and their ${ }^{1} \mathrm{H}-$ NMR spectra show an ABCD spin system (four multiplets) for the $\mathrm{C}_{5} \mathrm{H}_{4}$ ring protons, an $\mathrm{ABC}$ spin system (three multiplets) for the $\mathrm{C}_{5} \mathrm{H}_{3}$ ring protons, two singlets for the diastereotopic methyl-silyl groups and three singlets for the tert-butyl protons. Similar spectroscopic features were also observed in the ${ }^{13} \mathrm{C}\left\{{ }^{1} \mathrm{H}\right\}$-NMR spectra which show six different resonances assigned to the carbon atoms of the cyclopentadienyl rings, one resonance for the $\mathrm{SiMe}_{2}$ group and the corresponding resonances for the tert-butyl groups are found for complexes 7. A more complicated ${ }^{13} \mathrm{C}$-NMR spectroscopic pattern was observed for complexes $\mathbf{8}$, due to the chirality of the metal centre. The chemical shift of the cyclopentadienyl $\mathrm{C}_{i p s o}$ atom in the $\mathrm{C}_{5} \mathrm{H}_{4}$ ring is typically shifted downfield from the average shift for the other ring carbon resonances in complexes 7 and upfield shifted in complexes $\mathbf{8}$. These observations are diagnostic of single $\eta^{5}$-coordination of the cyclopentadienyl ligand in complexes 7 and chelation of the appended amido group in the silyl-amido complexes $\mathbf{8}$.

Crystals of $\mathbf{8 b}$ suitable for X-ray diffraction were obtained by slow cooling of toluene-hexane solutions. The molecular structure of $\mathbf{8 b}$ is shown in Fig. 2 and selected bond distances and bond angles are given in Table 3.

The molecular structure is a typical metallocene system with the chlorine and the nitrogen atom located approximately in the bent metallocene wedge. The coordination around the zirconium can be considered tetrahedral if each cyclopentadienyl ring is taken as occupying a single coordination site. The zirconium atom in $\mathbf{8 b}$ is a chiral centre and in the unit cell, only the $\mathrm{R}$ isomer was found. 
The structural data for $\mathbf{8 b}$ are comparable to those found for other dicyclopentadienyl, ansa-dicyclopentadienyl and mixed dicyclopentadienyl zirconium complexes [20]. The (centroid)- $\mathrm{Zr}$-(centroid) angle for compound $\mathbf{8 b}\left(127.9^{\circ}\right)$ is within the expected range [21], although slightly smaller $\left(10^{\circ}\right)$ than that found in complexes with the same ditert-butylcyclopentadienyl ring or comparable bulky cyclopentadienyl ligands (bistrimethylsilylcyclopentadienyl or tritert-butylcyclopentadienyl rings). This feature could be due to the presence of a constrained ligand in $\mathbf{8 b}$, which compresses the geometry to a more tetrahedral disposition.

The value of the (centroid) $\mathrm{Zr}-\mathrm{N}$ angle $\left(100.3^{\circ}\right)$ compares very well with those reported previously for related ansa-cyclopentadienylsilyl-amido derivatives [8a,22], being smaller than the typical (centroid) $\mathrm{Zr}$-(centroid) angles found for the ansa-dicyclopentadienyl complexes [9a,23].

The sum of the angles around the nitrogen atom $\left[\mathrm{Si}(1)-\mathrm{N}(1)-\mathrm{C}(31), \quad 120.7(4)^{\circ}, \quad \mathrm{Zr}(1)-\mathrm{N}(1)-\mathrm{C}(31)\right.$, $\left.135.0(4)^{\circ} ; \operatorname{Si}(1)-\mathrm{N}(1)-\mathrm{Zr}(1), 104.2(2)^{\circ}\right]\left(359.9^{\circ}\right)$, is indicative of a planar triangular disposition corresponding to its $\mathrm{sp}^{2}$ hybridisation. The $\mathrm{Si}(1)-\mathrm{N}(1)-\mathrm{Zr}(1)$ angle is $15^{\circ}$ smaller while the $\operatorname{Zr}(1)-\mathrm{N}(1)-\mathrm{C}(31)$ angle is opened by almost the same amount with respect to the remaining $\mathrm{Si}(1)-\mathrm{N}(1)-\mathrm{C}(31)$ angle with a value of $120.7(4)^{\circ}$. The co-planarity of the zirconium, nitrogen,

Table 3

Selected bond distances $(\AA)$ and bond angles $\left(^{\circ}\right)$ for compound $\mathbf{8 b}$

\begin{tabular}{|c|c|c|c|}
\hline \multicolumn{4}{|l|}{ Bond distances } \\
\hline $\mathrm{Zr}(1)-\mathrm{N}(1)$ & $2.124(4)$ & $\mathrm{C}(21)-\mathrm{C}(22)$ & $1.414(8)$ \\
\hline $\operatorname{Zr}(1)-\mathrm{Cp} 1$ & 2.226 & $\mathrm{Zr}(1)-\mathrm{Cp} 2$ & 2.272 \\
\hline $\mathrm{Zr}(1)-\mathrm{Cl}(1)$ & $2.470(2)$ & $\mathrm{C}(21)-\mathrm{C}(211)$ & $1.531(9)$ \\
\hline $\operatorname{Zr}(1)-\mathrm{C}(11)$ & $2.450(6)$ & $\mathrm{C}(22)-\mathrm{C}(23)$ & $1.398(8)$ \\
\hline $\operatorname{Zr}(1)-C(12)$ & $2.487(7)$ & $\mathrm{C}(23)-\mathrm{C}(24)$ & $1.411(8)$ \\
\hline $\operatorname{Zr}(1)-C(13)$ & $2.585(7)$ & $\mathrm{C}(23)-\mathrm{C}(231)$ & $1.527(9)$ \\
\hline $\operatorname{Zr}(1)-C(14)$ & $2.591(6)$ & $\mathrm{C}(24)-\mathrm{C}(25)$ & $1.387(8)$ \\
\hline $\operatorname{Zr}(1)-C(15)$ & $2.514(6)$ & $\mathrm{Si}(1)-\mathrm{N}(1)$ & $1.747(5)$ \\
\hline $\operatorname{Zr}(1)-\mathrm{C}(21)$ & $2.586(6)$ & $\mathrm{Si}(1)-\mathrm{C}(112)$ & $1.857(7)$ \\
\hline $\operatorname{Zr}(1)-\mathrm{C}(22)$ & $2.595(6)$ & $\mathrm{Si}(1)-\mathrm{C}(111)$ & $1.862(6)$ \\
\hline $\operatorname{Zr}(1)-\mathrm{C}(23)$ & $2.612(6)$ & $\mathrm{C}(211)-\mathrm{C}(212)$ & $1.508(9)$ \\
\hline $\mathrm{Zr}(1)-\mathrm{C}(24)$ & $2.522(6)$ & $\mathrm{C}(211)-\mathrm{C}(213)$ & $1.537(8)$ \\
\hline $\operatorname{Zr}(13)-\mathrm{C}(25)$ & $2.516(5)$ & $C(211)-C(214)$ & $1.545(8)$ \\
\hline$C(11)-C(15)$ & $1.415(8)$ & $C(231)-C(232)$ & $1.523(9)$ \\
\hline $\mathrm{C}(11)-\mathrm{C}(12)$ & $1.414(9)$ & $\mathrm{C}(231)-\mathrm{C}(233)$ & $1.533(9)$ \\
\hline $\mathrm{C}(11)-\mathrm{Si}(1)$ & $1.852(6)$ & $\mathrm{C}(231)-\mathrm{C}(234)$ & $1.532(9)$ \\
\hline $\mathrm{C}(12)-\mathrm{C}(13)$ & $1.386(9)$ & $\mathrm{N}(1)-\mathrm{C}(31)$ & $1.498(8)$ \\
\hline$C(13)-C(14)$ & $1.39(1)$ & $\mathrm{C}(31)-\mathrm{C}(33)$ & $1.52(1)$ \\
\hline$C(14)-C(15)$ & $1.406(9)$ & $\mathrm{C}(31)-\mathrm{C}(34)$ & $1.53(1)$ \\
\hline $\mathrm{C}(21)-\mathrm{C}(25)$ & $1.403(8)$ & $\mathrm{C}(31)-\mathrm{C}(32)$ & $1.550(9)$ \\
\hline \multicolumn{4}{|l|}{ Bond angles } \\
\hline $\mathrm{Cl}(1)-\mathrm{Zr}(1)-\mathrm{N}(1)$ & $96.0(1)$ & $\mathrm{Cp} 1-\mathrm{Zr}(1)-\mathrm{Cp} 2$ & 127.9 \\
\hline $\mathrm{Cl}(1)-\operatorname{Zr}(1)-\mathrm{Cp} 1$ & 104.3 & $\mathrm{~N}(1)-\operatorname{Zr}(1)-\mathrm{Cp} 1$ & 100.3 \\
\hline $\mathrm{Cl}(1)-\mathrm{Zr}(1)-\mathrm{Cp} 2$ & 106.5 & $\mathrm{~N}(1)-\operatorname{Zr}(1)-\mathrm{Cp} 2$ & 116.9 \\
\hline $\mathrm{N}(1)-\mathrm{Si}(1)-\mathrm{C}(11)$ & $95.2(2)$ & $\mathrm{Si}(1)-\mathrm{N}(1)-\operatorname{Zr}(1)$ & $104.2(2)$ \\
\hline $\mathrm{Si}(1)-\mathrm{N}(1)-\mathrm{C}(31)$ & $120.7(4)$ & $\mathrm{Zr}(1)-\mathrm{N}(1)-\mathrm{C}(31)$ & $135.0(4)$ \\
\hline
\end{tabular}

silicon and the tert-butyl ligand $\mathrm{C}_{i p s o}$ atoms and the smaller values observed for the $\mathrm{Si}(1)-\mathrm{N}(1)-\mathrm{Zr}(1)$ and $\mathrm{N}(1)-\mathrm{Si}(1)-\mathrm{C}(11)$ angles with respect to the theoretical values of 120 and $109^{\circ}$, respectively, is consistent with the behaviour known for these types of constrained geometry cyclopentadienylsilyl-amido complexes.

The $\mathrm{Zr}(1)-\mathrm{N}(1)$ [2.124(4) $\AA$ ] and $\mathrm{Si}(1)-\mathrm{N}(1)$ [1.747(5) $\AA$ A] bond distances are similar to those found for analogous interactions [24] and shorter than the estimated addition of the corresponding covalent radii, indicating the $\mathrm{Zr}-\mathrm{N}$ and $\mathrm{Si}-\mathrm{N}$ double-bond character with competition between the silicon and the zirconium atoms for $\pi$-bonding with the nitrogen lone pair leading to the electronic delocalisation along the $\mathrm{Si}-\mathrm{N}-\mathrm{Zr}$ system.

A slight deviation from $\eta^{5}$-coordination of the silylsubstituted cyclopentadienyl ligand in compound $\mathbf{8 b}$ is observed, as deduced from the small differences in the $\mathrm{Zr}-\mathrm{C}$ (ring) $(0.141 \AA)$ and the $\mathrm{C}-\mathrm{C}$ ring distances and the distance from the silicon atom to the $\mathrm{Cp}$ plane (0.7986 ̊).

\section{Experimental}

\subsection{General considerations}

All manipulations were performed under argon using Schlenk and high-vacuum line techniques or a glovebox model HE-63. The following solvents were purified by distillation under argon before use by employing the appropriate drying/deoxygenated agent: toluene (sodium), hexane and heptane (sodium-potassium amalgam) and diethyl ether (sodium-benzophenone). $\mathrm{TiCl}_{4}$ (Fluka), $\mathrm{HfCl}_{4}$ (Aldrich), $\mathrm{TlOC}_{2} \mathrm{H}_{5}$ (Panreac), $\mathrm{NEt}_{3}$ (Fluka) and $\mathrm{NH}_{2}^{t} \mathrm{Bu}$ (Aldrich) were distilled before use and stored over $4 \AA$ molecular sieves. Ti $\left(\eta^{5}\right.$ $\left.\mathrm{C}_{5} \mathrm{H}_{4} \mathrm{SiClMe}_{2}\right) \mathrm{Cl}_{3}$ [9a], $\mathrm{Zr}\left(\eta^{5}-\mathrm{C}_{5} \mathrm{H}_{4} \mathrm{SiMe}_{2} \mathrm{Cl}\right) \mathrm{Cl}_{3}$ [9a], $\left(\mathrm{C}_{5} \mathrm{H}_{4}\right)\left(\mathrm{SiClMe}_{2}\right)\left(\mathrm{SiMe}_{3}\right)$ [9a,25], $\mathrm{C}_{5} \mathrm{H}_{5} \mathrm{SiClMe}_{2}$ [26], 1,3${ }^{t} \mathrm{Bu}_{2} \mathrm{C}_{5} \mathrm{H}_{4}$ [27], $\mathrm{Tl}\left(\mathrm{C}_{5} \mathrm{H}_{5}\right)$ [28] and $\mathrm{K}\left(\mathrm{C}_{5} \mathrm{Me}_{5}\right)$ [29] were prepared by known procedures. $\mathrm{LiNH}^{t} \mathrm{Bu}$ was quantitatively prepared by reaction of $\mathrm{NH}_{2}^{t} \mathrm{Bu}$ with $\mathrm{Li}^{n} \mathrm{Bu}$ in hexane. $\mathrm{C}, \mathrm{H}$ and $\mathrm{N}$ microanalyses were performed on a Perkin-Elmer 240B and/or Heraeus CHN-O-rapid microanalyzer. Electron impact (EI) mass spectra were recorded at $70 \mathrm{eV}$ on a Hewlett-Packard 5988 spectrometer and IR spectra were recorded on a PerkinElmer 883 spectrophotometer using $\mathrm{KBr}$ pellets; only selected MS and IR data are reported. NMR spectra, measured at $25^{\circ} \mathrm{C}$, were recorded on a Varian Unity FT-300 $\left({ }^{1} \mathrm{H}-\mathrm{NMR}\right.$ at $300 \mathrm{MHz},{ }^{13} \mathrm{C}-\mathrm{NMR}$ at $\left.75 \mathrm{MHz}\right)$ or FT-500 $\left({ }^{1} \mathrm{H}-\mathrm{NMR}\right.$ at $500 \mathrm{MHz},{ }^{13} \mathrm{C}-\mathrm{NMR}$ at 125 $\mathrm{MHz}$ ) spectrometer and chemical shifts are referenced to residual protons or carbons of the deuterated solvents. 


\subsection{Synthesis of $\mathrm{Tl}\left(1,3-{ }^{t} \mathrm{Bu}_{2} \mathrm{C}_{5} \mathrm{H}_{3}\right)$}

$1,3-{ }^{t} \mathrm{Bu}_{2} \mathrm{C}_{5} \mathrm{H}_{4}(1.85 \mathrm{ml}, 1.56 \mathrm{~g}, 8.73 \mathrm{mmol})$ was added dropwise to a solution of $\mathrm{TlOC}_{2} \mathrm{H}_{5}(0.61 \mathrm{ml}, 2.18 \mathrm{~g}$, $8.73 \mathrm{mmol}$ ) in diethyl ether cooled at $0^{\circ} \mathrm{C}$. The reaction mixture was stirred for $8 \mathrm{~h}$ at room temperature (r.t.) to give a pale yellow solid. After filtration, the solid was washed with hexane $(2 \times 10 \mathrm{ml})$, dried under vacuum and characterised as $\mathrm{Tl}\left(1,3{ }^{t} \mathrm{Bu}_{2} \mathrm{C}_{5} \mathrm{H}_{3}\right)(1.0 \mathrm{~g}, 2.62$ mmol, $30 \%$ yield). Anal. Calc. for $\mathrm{C}_{13} \mathrm{H}_{21}$ Tl: $\mathrm{C}, 40.91$; $\mathrm{H}$, 5.55. Found: C, 41.62; H, 6.02\%. ${ }^{1} \mathrm{H}-\mathrm{NMR}(300$ $\left.\mathrm{MHz}, \mathrm{C}_{6} \mathrm{D}_{6}, 25^{\circ} \mathrm{C}\right): \delta 1.29\left(\mathrm{~s}, 18 \mathrm{H},{ }^{t} \mathrm{Bu}\right), 5.80\left(\mathrm{AA}^{\prime}, 2 \mathrm{H}\right.$, $\left.\mathrm{C}_{5} \mathrm{H}_{3}\right), 6.11\left(\mathrm{~B}, 1 \mathrm{H}, \mathrm{C}_{5} \mathrm{H}_{3}\right) .{ }^{13} \mathrm{C}-\left\{{ }^{1} \mathrm{H}\right\}$ NMR $(75 \mathrm{MHz}$, $\left.\mathrm{CDCl}_{3}, 25^{\circ} \mathrm{C}\right): \delta 31.3\left(\mathrm{C}_{\text {ipso }},{ }^{t} \mathrm{Bu}\right), 34.4\left({ }^{t} \mathrm{Bu}\right), 101.5$, $102.9\left(\mathrm{C}_{5} \mathrm{H}_{3}\right), 139.1\left(\mathrm{C}_{\text {ipsos }}, \mathrm{C}_{5} \mathrm{H}_{3}\right)$. MS (EI) $m / z: 382$ $[\mathrm{M}]^{+}(7 \%) ; 205[\mathrm{Tl}]^{+}(100 \%)$.

\subsection{Synthesis of $\mathrm{Hf}\left(\eta^{5}-\mathrm{C}_{5} \mathrm{H}_{4} \mathrm{SiClMe}_{2}\right) \mathrm{Cl}_{3}$ (1c)}

A solution of $\mathrm{C}_{5} \mathrm{H}_{4}\left(\mathrm{SiClMe}_{2}\right)\left(\mathrm{SiMe}_{3}\right)(1.15 \mathrm{ml}, 1.04 \mathrm{~g}$, $4.5 \mathrm{mmol})$ in heptane was added to a suspension of $\mathrm{HfCl}_{4}(1.30 \mathrm{~g}, 4.06 \mathrm{mmol})$ in $50 \mathrm{ml}$ of the same solvent. The Schlenk was connected to a bubbler and the reaction mixture was refluxed with vigorous stirring for $1 \mathrm{~h}$. The formation of a brown solution was observed when the $\mathrm{HfCl}_{4}$ reacted gradually. After filtration, the hot solution was concentrated $(30 \mathrm{ml})$ and cooled to $30^{\circ} \mathrm{C}$ to give a white solid which was recrystallised in toluene-hexane to give 1c as a microcrystalline solid (1 g, $2.26 \mathrm{mmol}, 56 \%$ yield). Anal. Calc. for $\mathrm{C}_{7} \mathrm{H}_{10} \mathrm{SiCl}_{4} \mathrm{Hf}: \mathrm{C}, 18.99 ; \mathrm{H}, 2.27$. Found: C, 19.36; H, $2.48 \% .{ }^{1} \mathrm{H}-\mathrm{NMR}\left(300 \mathrm{MHz}, \mathrm{CDCl}_{3}, 25^{\circ} \mathrm{C}\right): \delta 0.77$ (s, $\left.6 \mathrm{H}, \mathrm{SiClMe}_{2}\right), 6.90\left(\mathrm{AA}^{\prime}, 2 \mathrm{H}, \mathrm{C}_{5} \mathrm{H}_{4}\right), 7.02\left(\mathrm{BB}^{\prime}, 2 \mathrm{H}\right.$, $\left.\mathrm{C}_{5} \mathrm{H}_{4}\right) . \quad\left(300 \mathrm{MHz}, \mathrm{C}_{6} \mathrm{D}_{6}, \quad 25^{\circ} \mathrm{C}\right): \delta \quad 0.43 \quad(\mathrm{~s}, \quad 6 \mathrm{H}$, $\left.\mathrm{SiClMe}_{2}\right), 5.91\left(\mathrm{AA}^{\prime}, 2 \mathrm{H}, \mathrm{C}_{5} \mathrm{H}_{4}\right), 6.25\left(\mathrm{BB}^{\prime}, 2 \mathrm{H}, \mathrm{C}_{5} \mathrm{H}_{4}\right)$. ${ }^{13} \mathrm{C}-\left\{{ }^{1} \mathrm{H}\right\} \quad$ NMR $\left(75 \mathrm{MHz}, \mathrm{CDCl}_{3}, \quad 25^{\circ} \mathrm{C}\right): \quad \delta 2.7$ $\left(\mathrm{SiClMe}_{2}\right), 123.6,126.6\left(\mathrm{C}_{2}-\mathrm{C}_{5}, \mathrm{C}_{5} \mathrm{H}_{4}\right), 131.5\left(\mathrm{C}_{i p s o}\right.$, $\left.\mathrm{C}_{5} \mathrm{H}_{4}\right)$. MS (EI) $m / z: 442[\mathrm{M}]^{+}(4 \%) ; 407[\mathrm{M}-\mathrm{Cl}]^{+}$ $(5 \%) ; 122\left[\mathrm{C}_{5} \mathrm{H}_{4} \mathrm{SiMe}_{2}\right]^{+}(100 \%)$.

\subsection{Synthesis of $\mathrm{Ti}\left(\eta^{5}-\mathrm{C}_{5} \mathrm{H}_{4} \mathrm{SiClMe}_{2}\right)_{2} \mathrm{Cl}_{2}$ (2a)}

$\mathrm{C}_{5} \mathrm{H}_{5}\left(\mathrm{SiClMe}_{2}\right)(7.39 \mathrm{ml}, 7.39 \mathrm{~g}, 46.57 \mathrm{mmol})$ was added to a solution containing $\mathrm{TiCl}_{4}(2.56 \mathrm{ml}, 4.41 \mathrm{~g}$, $23.28 \mathrm{mmol})$ and $\mathrm{NEt}_{3}(6.77 \mathrm{ml}, 4.71 \mathrm{~g}, 46.57 \mathrm{mmol})$ in toluene $(100 \mathrm{ml})$. The mixture was refluxed with stirring for $3 \mathrm{~h}$ and the formation of insoluble $\mathrm{Et}_{3} \mathrm{~N} \cdot \mathrm{HCl}$, was observed. After filtration, the solution was concentrated and cooled to $-30^{\circ} \mathrm{C}$ affording a solid which was washed with cold hexane $(2 \times 15 \mathrm{ml})$ and recrystallised from toluene-hexane to give $\mathbf{2 a}$ as a red microcrystalline solid (4.7 g, $10.8 \mathrm{mmol}, 46 \%)$. Anal. Calc. for $\mathrm{C}_{14} \mathrm{H}_{20} \mathrm{Si}_{2} \mathrm{Cl}_{4} \mathrm{Ti}: \mathrm{C}, 38.73 ; \mathrm{H}, 4.64$. Found: $\mathrm{C}, 39.05 ; \mathrm{H}$, $4.71 \%$. ${ }^{1} \mathrm{H}-\mathrm{NMR}\left(300 \mathrm{MHz}, \mathrm{CDCl}_{3}, 25^{\circ} \mathrm{C}\right): \delta 0.74(\mathrm{~s}$, $\left.6 \mathrm{H}, \mathrm{SiClMe}_{2}\right), 6.62\left(\mathrm{AA}^{\prime}, 2 \mathrm{H}, \mathrm{C}_{5} \mathrm{H}_{4}\right), 6.86\left(\mathrm{BB}^{\prime}, 2 \mathrm{H}\right.$, $\left.\mathrm{C}_{5} \mathrm{H}_{4}\right) .\left(300 \mathrm{MHz}, \mathrm{C}_{6} \mathrm{D}_{6}, \quad 25^{\circ} \mathrm{C}\right): \delta 0.74(\mathrm{~s}, \quad 6 \mathrm{H}$,
$\left.\mathrm{SiClMe}_{2}\right), 5.69\left(\mathrm{AA}^{\prime}, 2 \mathrm{H}, \mathrm{C}_{5} \mathrm{H}_{4}\right), 6.40\left(\mathrm{BB}^{\prime}, 2 \mathrm{H}, \mathrm{C}_{5} \mathrm{H}_{4}\right)$. ${ }^{13} \mathrm{C}-\left\{{ }^{1} \mathrm{H}\right\} \quad \mathrm{NMR} \quad\left(75 \mathrm{MHz}, \mathrm{CDCl}_{3}, \quad 25^{\circ} \mathrm{C}\right): \quad \delta \quad 2.9$ $\left(\mathrm{SiClMe}_{2}\right), 120.9,129.1\left(\mathrm{C}_{5} \mathrm{H}_{4}\right), 128.1\left(\mathrm{C}_{\text {ipso }}, \mathrm{C}_{5} \mathrm{H}_{4}\right) . \mathrm{MS}$ (EI) $m / z: 434[\mathrm{M}]^{+}(10 \%) ; 362[\mathrm{M}-2 \mathrm{Cl}]^{+}(100 \%) ; 122$ $\left[\mathrm{C}_{5} \mathrm{H}_{4} \mathrm{SiMe}_{2}\right]^{+}(66 \%), 107\left[\mathrm{C}_{5} \mathrm{H}_{4} \mathrm{SiMe}\right]^{+}(31 \%)$.

\subsection{Synthesis of $\mathrm{Hf}\left(\eta^{5}-\mathrm{C}_{5} \mathrm{H}_{4} \mathrm{SiClMe}_{2}\right)_{2} \mathrm{Cl}_{2}(2 \mathrm{c})$}

$\mathrm{C}_{5} \mathrm{H}_{5}\left(\mathrm{SiClMe}_{2}\right)(0.93 \mathrm{ml}, 0.93 \mathrm{~g}, 5.9 \mathrm{mmol})$ was added to a solution containing $\mathrm{HfCl}_{4}(0.95 \mathrm{~g}, 2.95 \mathrm{mmol})$ and $\mathrm{NEt}_{3}(0.86 \mathrm{ml}, 0.60 \mathrm{~g}, 5.9 \mathrm{mmol})$ in toluene $(100 \mathrm{ml})$. The mixture was refluxed with stirring for $3 \mathrm{~h}$. The insoluble $\mathrm{Et}_{3} \mathrm{~N} \cdot \mathrm{HCl}$ precipitate, was filtered off and the solution was concentrated and cooled to $-30^{\circ} \mathrm{C}$ affording a light brown solid which was washed with cold hexane $(2 \times 15 \mathrm{ml})$ and recrystallised from toluenehexane to give $2 \mathrm{c}(1 \mathrm{~g}, 1.77 \mathrm{mmol}, 60 \%)$. Anal. Calc. for $\mathrm{C}_{14} \mathrm{H}_{20} \mathrm{Si}_{2} \mathrm{Cl}_{4} \mathrm{Hf}: \mathrm{C}, 29.77 ; \mathrm{H}, 3.57$. Found: C, 30.05; H, $4.00 \%$. ${ }^{1} \mathrm{H}-\mathrm{NMR}\left(300 \mathrm{MHz}, \mathrm{CDCl}_{3}, 25^{\circ} \mathrm{C}\right): \delta 0.72$ (s, $\left.6 \mathrm{H}, \mathrm{SiClMe}_{2}\right), 6.49\left(\mathrm{AA}^{\prime}, 2 \mathrm{H}, \mathrm{C}_{5} \mathrm{H}_{4}\right), 6.70\left(\mathrm{BB}^{\prime}, 2 \mathrm{H}\right.$, $\left.\mathrm{C}_{5} \mathrm{H}_{4}\right) . \quad\left(300 \mathrm{MHz}, \mathrm{C}_{6} \mathrm{D}_{6}, \quad 25^{\circ} \mathrm{C}\right): \delta 0.65 \quad(\mathrm{~s}, \quad 6 \mathrm{H}$, $\left.\mathrm{SiClMe}_{2}\right), 5.76\left(\mathrm{AA}^{\prime}, 2 \mathrm{H}, \mathrm{C}_{5} \mathrm{H}_{4}\right), 6.29\left(\mathrm{BB}^{\prime}, 2 \mathrm{H}, \mathrm{C}_{5} \mathrm{H}_{4}\right)$. ${ }^{13} \mathrm{C}-\left\{{ }^{1} \mathrm{H}\right\} \quad \mathrm{NMR} \quad\left(75 \mathrm{MHz}, \mathrm{CDCl}_{3}, \quad 25^{\circ} \mathrm{C}\right): \quad \delta \quad 3.1$ $\left(\mathrm{SiClMe}_{2}\right), 115.3,125.6\left(\mathrm{C}_{5} \mathrm{H}_{4}\right), 120.0\left(\mathrm{C}_{\text {ipso }}, \mathrm{C}_{5} \mathrm{H}_{4}\right) . \mathrm{MS}$ (EI) $m / z: 564[\mathrm{M}]^{+}(1 \%) ; 407\left[\mathrm{M}-\mathrm{C}_{5} \mathrm{H}_{4} \mathrm{SiClMe}_{2}\right]^{+}$ $(100 \%) ; 122\left[\mathrm{C}_{5} \mathrm{H}_{4} \mathrm{SiMe}_{2}\right]^{+}(82 \%), 107\left[\mathrm{C}_{5} \mathrm{H}_{4} \mathrm{SiMe}\right]^{+}$ $(25 \%)$.

\subsection{Synthesis of \\ $\mathrm{Ti}\left\{\left(\eta^{5}-\mathrm{C}_{5} \mathrm{H}_{4}\right) \mathrm{SiMe}_{2} \mathrm{OSiMe}_{2}\left(\eta^{5}-\mathrm{C}_{5} \mathrm{H}_{4}\right)\right\} \mathrm{Cl}_{2}(\mathbf{3 a})$}

Water $(50 \mu 1,0.05 \mathrm{~g}, 2.8 \mathrm{mmol})$ was added to a solution of $\mathrm{Ti}\left(\eta^{5}-\mathrm{C}_{5} \mathrm{H}_{4} \mathrm{SiClMe}_{2}\right)_{2} \mathrm{Cl}_{2}(1.21 \mathrm{~g}, 2.8 \mathrm{mmol})$ in toluene $(50 \mathrm{ml})$. The mixture was stirred for $2 \mathrm{~h}$ at r.t. and then concentrated and cooled to $-30^{\circ} \mathrm{C}$ affording a red microcrystalline solid which was washed with hexane $(2 \times 15 \mathrm{ml})$, recrystallised from toluenehexane and characterised as $\mathbf{3 a}(0.41 \mathrm{~g}, 2.1 \mathrm{mmol}, 77 \%)$. Anal. Calc. for $\mathrm{C}_{14} \mathrm{H}_{20} \mathrm{Si}_{2} \mathrm{Cl}_{2} \mathrm{OTi}$ : C, 44.34; $\mathrm{H}, 5.32$. Found: C, 44.02; H, 5.41\%. ${ }^{1} \mathrm{H}-\mathrm{NMR}(300 \mathrm{MHz}$, $\left.\mathrm{CDCl}_{3}, 25^{\circ} \mathrm{C}\right): \delta 0.12$ (s, 6H, $\left.\mathrm{SiMe}_{2}\right), 6.61\left(\mathrm{AA}^{\prime}, 2 \mathrm{H}\right.$, $\left.\mathrm{C}_{5} \mathrm{H}_{4}\right), 6.93\left(\mathrm{BB}^{\prime}, 2 \mathrm{H}, \mathrm{C}_{5} \mathrm{H}_{4}\right) .\left(300 \mathrm{MHz}, \mathrm{C}_{6} \mathrm{D}_{6}, 25^{\circ} \mathrm{C}\right): \delta$ $0.20\left(\mathrm{~s}, 6 \mathrm{H}, \mathrm{SiMe}_{2}\right), 6.16\left(\mathrm{AA}^{\prime}, 2 \mathrm{H}, \mathrm{C}_{5} \mathrm{H}_{4}\right), 6.50\left(\mathrm{BB}^{\prime}\right.$, $\left.2 \mathrm{H}, \mathrm{C}_{5} \mathrm{H}_{4}\right) \cdot{ }^{13} \mathrm{C}-\left\{{ }^{1} \mathrm{H}\right\}$ NMR $\left(75 \mathrm{MHz}, \mathrm{CDCl}_{3}, 25^{\circ} \mathrm{C}\right): \delta$ $0.4\left(\mathrm{SiMe}_{2}\right), 119.0,124.7\left(\mathrm{C}_{5} \mathrm{H}_{4}\right), 115.6\left(\mathrm{C}_{\text {ipso }}, \mathrm{C}_{5} \mathrm{H}_{4}\right)$. MS (EI) $m / z: 378[\mathrm{M}]^{+}(13 \%) ; 308[\mathrm{M}-2 \mathrm{Cl}]^{+}(43 \%)$; $122\left[\mathrm{C}_{5} \mathrm{H}_{4} \mathrm{SiMe}_{2}\right]^{+}(100 \%) ; 107\left[\mathrm{C}_{5} \mathrm{H}_{4} \mathrm{SiMe}\right]^{+}(46 \%)$.

\subsection{Synthesis of \\ $\mathrm{Hf}\left\{\left(\eta^{5}-\mathrm{C}_{5} \mathrm{H}_{4}\right) \mathrm{SiMe}_{2} \mathrm{OSiMe}_{2}\left(\eta^{5}-\mathrm{C}_{5} \mathrm{H}_{4}\right)\right\} \mathrm{Cl}_{2}(\mathbf{3 c})$}

Water $(30 \mu 1,0.03 \mathrm{~g}, 1.96 \mathrm{mmol})$ was added to a solution containing $1.11 \mathrm{~g}$ of $\mathrm{Hf}\left(\eta^{5}-\mathrm{C}_{5} \mathrm{H}_{4} \mathrm{SiClMe}_{2}\right)_{2} \mathrm{Cl}_{2}$ $(1.96 \mathrm{mmol})$ in toluene $(50 \mathrm{ml})$. The mixture was stirred 
for $12 \mathrm{~h}$ and then concentrated and cooled to $-30^{\circ} \mathrm{C}$ to give a white microcrystalline solid which was washed with hexane $(2 \times 15 \mathrm{ml})$, recrystallised from toluenehexane and characterised as 3c $(1.0 \mathrm{~g}, 1.96 \mathrm{mmol}$, $100 \%$ ). Anal. Calc. for $\mathrm{C}_{14} \mathrm{H}_{20} \mathrm{Si}_{2} \mathrm{Cl}_{2} \mathrm{OHf}$ : C, 32.98; $\mathrm{H}$, 3.95. Found: C, 32.62; H, 3.98\%. ${ }^{1} \mathrm{H}-\mathrm{NMR}(300 \mathrm{MHz}$, $\left.\mathrm{CDCl}_{3}, 25^{\circ} \mathrm{C}\right): \delta 0.37\left(\mathrm{~s}, 6 \mathrm{H}, \mathrm{SiMe}_{2}\right), 6.43\left(\mathrm{AA}^{\prime}, 2 \mathrm{H}\right.$, $\left.\mathrm{C}_{5} \mathrm{H}_{4}\right), 6.76\left(\mathrm{BB}^{\prime}, 2 \mathrm{H}, \mathrm{C}_{5} \mathrm{H}_{4}\right) .\left(300 \mathrm{MHz}, \mathrm{C}_{6} \mathrm{D}_{6}, 25^{\circ} \mathrm{C}\right): \delta$ $0.25\left(\mathrm{~s}, 6 \mathrm{H}, \mathrm{SiMe}_{2}\right), 6.18\left(\mathrm{AA}^{\prime}, 2 \mathrm{H}, \mathrm{C}_{5} \mathrm{H}_{4}\right), 6.35\left(\mathrm{BB}^{\prime}\right.$, $\left.2 \mathrm{H}, \mathrm{C}_{5} \mathrm{H}_{4}\right) \cdot{ }^{13} \mathrm{C}-\left\{{ }^{1} \mathrm{H}\right\}$ NMR $\left(75 \mathrm{MHz}, \mathrm{CDCl}_{3}, 25^{\circ} \mathrm{C}\right): \delta$ $0.9\left(\mathrm{SiMe}_{2}\right), 119.6,129.9\left(\mathrm{C}_{5} \mathrm{H}_{4}\right), 114.5\left(\mathrm{C}_{i p s o}, \mathrm{C}_{5} \mathrm{H}_{4}\right)$. MS (EI) $m / z: 510[\mathrm{M}]^{+}(8 \%) ; 495[\mathrm{M}-2 \mathrm{Cl}+\mathrm{H}]^{+}$ $(75 \%) ; 122\left[\mathrm{C}_{5} \mathrm{H}_{4} \mathrm{SiMe}_{2}\right]^{+}(100 \%) ; 107\left[\mathrm{C}_{5} \mathrm{H}_{4} \mathrm{SiMe}\right]^{+}$ $(36 \%)$.

\subsection{Synthesis of \\ $\mathrm{Ti}\left(\eta^{5}-1,3^{t} \mathrm{Bu}_{2} \mathrm{C}_{5} \mathrm{H}_{3}\right)\left(\eta^{5}-\mathrm{C}_{5} \mathrm{H}_{4} \mathrm{SiClMe}_{2}\right) \mathrm{Cl}_{2}$ (4a)}

$\mathrm{Tl}\left(1,3-{ }^{t} \mathrm{Bu}_{2} \mathrm{C}_{5} \mathrm{H}_{3}\right)(1.40 \mathrm{~g}, 3.67 \mathrm{mmol})$ was added to a solution of $\mathrm{Ti}\left(\eta^{5}-\mathrm{C}_{5} \mathrm{H}_{4} \mathrm{SiClMe}_{2}\right) \mathrm{Cl}_{3}(1.15 \mathrm{~g}, 3.67 \mathrm{mmol})$ in toluene $(35 \mathrm{ml})$. The reaction mixture was refluxed with stirring for $12 \mathrm{~h}$. After filtration, the resulting solution was concentrated $(15 \mathrm{ml})$ and cooled to $-30^{\circ} \mathrm{C}$ to give a solid which was washed with hexane $(2 \times 10 \mathrm{ml})$ and recrystallised from toluene-hexane. The resulting red microcrystalline solid was characterised as $4 \mathbf{a}(1.0 \mathrm{~g}, 2.20 \mathrm{mmol}, 60 \%$ yield). Anal. Calc. for $\mathrm{C}_{20} \mathrm{H}_{31} \mathrm{SiCl}_{3} \mathrm{Ti}$ : C, 53.21; H, 6.74. Found: $\mathrm{C}, 52.93 ; \mathrm{H}$, $6.89 \%$. ${ }^{1} \mathrm{H}-\mathrm{NMR}\left(300 \mathrm{MHz}, \mathrm{C}_{6} \mathrm{D}_{6}, 25^{\circ} \mathrm{C}\right): \delta 0.92(\mathrm{~s}, 6 \mathrm{H}$, $\left.\mathrm{SiClMe}_{2}\right), 1.12\left(\mathrm{~s}, 18 \mathrm{H},{ }^{t} \mathrm{Bu}\right), 5.57\left(\mathrm{AA}^{\prime}, 2 \mathrm{H}, \mathrm{C}_{5} \mathrm{H}_{3}\right), 5.95$ $\left(\mathrm{AA}^{\prime}, 2 \mathrm{H}, \mathrm{C}_{5} \mathrm{H}_{4}\right), 6.42\left(\mathrm{~B}, 1 \mathrm{H}, \mathrm{C}_{5} \mathrm{H}_{3}\right), 6.52\left(\mathrm{BB}^{\prime}, 2 \mathrm{H}\right.$, $\left.\mathrm{C}_{5} \mathrm{H}_{4}\right)$. $\left(300 \mathrm{MHz}, \mathrm{CDCl}_{3}, 25^{\circ} \mathrm{C}\right): \delta 0.76(\mathrm{~s}, 6 \mathrm{H}$, $\left.\mathrm{SiClMe}_{2}\right), 1.20\left(\mathrm{~s}, 18 \mathrm{H},{ }^{t} \mathrm{Bu}\right), 6.36\left(\mathrm{~B}, 1 \mathrm{H}, \mathrm{C}_{5} \mathrm{H}_{3}\right), 6.57$ $\left(\mathrm{AA}^{\prime}, 2 \mathrm{H}, \mathrm{C}_{5} \mathrm{H}_{3}\right), 6.62\left(\mathrm{AA}^{\prime}, 2 \mathrm{H}, \mathrm{C}_{5} \mathrm{H}_{4}\right), 6.66\left(\mathrm{BB}^{\prime}, 2 \mathrm{H}\right.$, $\left.\mathrm{C}_{5} \mathrm{H}_{4}\right) \cdot{ }^{13} \mathrm{C}-\left\{{ }^{1} \mathrm{H}\right\}$ NMR $\left(75 \mathrm{MHz}, \mathrm{CDCl}_{3}, 25^{\circ} \mathrm{C}\right): \delta 3.3$ $\left(\mathrm{SiClMe}_{2}\right), 30.9\left({ }^{t} \mathrm{Bu}\right), 35.1\left(\mathrm{C}_{i p s o},{ }^{t} \mathrm{Bu}\right), 115.0,115.7$ $\left(\mathrm{C}_{5} \mathrm{H}_{4}\right), 117.7\left(\mathrm{C}_{\text {ipso }}, \mathrm{C}_{5} \mathrm{H}_{4}\right), 118.3\left(\mathrm{C}_{2}, \mathrm{C}_{5} \mathrm{H}_{3}\right), 131.0$ $\left(\mathrm{C}_{4}-\mathrm{C}_{5}, \mathrm{C}_{5} \mathrm{H}_{3}\right), 151.9\left(\mathrm{C}_{\text {ipso }}, \mathrm{C}_{5} \mathrm{H}_{3}\right)$. MS (EI) $\mathrm{m} / \mathrm{z}: 453$ $[\mathrm{M}]^{+} \quad(2 \%) ; 275 \quad\left[\mathrm{M}-1,3\left({ }^{t} \mathrm{Bu}\right)_{2} \mathrm{C}_{5} \mathrm{H}_{3}\right]^{+} \quad(5 \%) ; 57$ $\left[\mathrm{Me}_{3} \mathrm{C}\right]^{+}(100 \%)$.

\subsection{Synthesis of}

$\mathrm{Zr}\left(\eta^{5}-1,3^{t} \mathrm{Bu}_{2} \mathrm{C}_{5} \mathrm{H}_{3}\right)\left(\eta^{5}-\mathrm{C}_{5} \mathrm{H}_{4} \mathrm{SiClMe}_{2}\right) \mathrm{Cl}_{2}(\mathbf{4 b})$

$\mathrm{Tl}\left(1,3-{ }^{t} \mathrm{Bu}_{2} \mathrm{C}_{5} \mathrm{H}_{3}\right)(1.02 \mathrm{~g}, 2.68 \mathrm{mmol})$ was added to a solution of $\mathrm{Zr}\left(\eta^{5}-\mathrm{C}_{5} \mathrm{H}_{4} \mathrm{SiClMe}_{2}\right) \mathrm{Cl}_{3}(0.95 \mathrm{~g}, 2.68 \mathrm{mmol})$ in toluene $(35 \mathrm{ml})$. The reaction mixture was refluxed with stirring for $14 \mathrm{~h}$. After filtration, the resulting solution was concentrated $(15 \mathrm{ml})$ and cooled to $-30^{\circ} \mathrm{C}$ to give a solid which was washed with hexane $(2 \times 10 \mathrm{ml})$ and recrystallised from toluene-hexane. The resulting white microcrystalline solid was characterised as $4 \mathbf{b}$ ( $1.0 \mathrm{~g}, 2.01 \mathrm{mmol}, 75 \%$ yield $)$. Anal. Calc. for $\mathrm{C}_{20} \mathrm{H}_{31} \mathrm{SiCl}_{3} \mathrm{Zr}$ : C, 47.85; H, 5.99. Found: C, 48.32; $\mathrm{H}, 6.28 \%$. ${ }^{1} \mathrm{H}-\mathrm{NMR}\left(300 \mathrm{MHz}, \mathrm{C}_{6} \mathrm{D}_{6}, 25^{\circ} \mathrm{C}\right): \delta 0.79$ (s, $\left.6 \mathrm{H}, \mathrm{SiClMe}_{2}\right), 1.15\left(\mathrm{~s}, 18 \mathrm{H},{ }^{t} \mathrm{Bu}\right), 5.85\left(\mathrm{AA}^{\prime}, 2 \mathrm{H}, \mathrm{C}_{5} \mathrm{H}_{3}\right.$ ),
$6.01\left(\mathrm{AA}^{\prime}, 2 \mathrm{H}, \mathrm{C}_{5} \mathrm{H}_{4}\right), 6.24\left(\mathrm{~B}, 1 \mathrm{H}, \mathrm{C}_{5} \mathrm{H}_{3}\right), 6.53\left(\mathrm{BB}^{\prime}\right.$, $\left.2 \mathrm{H}, \mathrm{C}_{5} \mathrm{H}_{4}\right) \cdot\left(300 \mathrm{MHz}, \mathrm{CDCl}_{3}, 25^{\circ} \mathrm{C}\right): \delta 0.75(\mathrm{~s}, 6 \mathrm{H}$, $\left.\mathrm{SiClMe}_{2}\right), 1.26\left(\mathrm{~s}, 18 \mathrm{H},{ }^{t} \mathrm{Bu}\right), 6.25\left(\mathrm{AA}^{\prime}, 2 \mathrm{H}, \mathrm{C}_{5} \mathrm{H}_{3}\right), 6.41$ $\left(\mathrm{B}, 1 \mathrm{H}, \mathrm{C}_{5} \mathrm{H}_{3}\right), 6.55\left(\mathrm{AA}^{\prime}, 2 \mathrm{H}, \mathrm{C}_{5} \mathrm{H}_{4}\right), 6.71\left(\mathrm{BB}^{\prime}, 2 \mathrm{H}\right.$, $\left.\mathrm{C}_{5} \mathrm{H}_{4}\right) \cdot{ }^{13} \mathrm{C}-\left\{{ }^{1} \mathrm{H}\right\}$ NMR $\left(125 \mathrm{MHz}, \mathrm{CDCl}_{3}, 25^{\circ} \mathrm{C}\right): \delta 3.1$ $\left(\mathrm{SiClMe}_{2}\right), 31.2\left({ }^{t} \mathrm{Bu}\right), 33.9\left(\mathrm{C}_{\text {ipso }},{ }^{t} \mathrm{Bu}\right), 110.8,114.0$ $\left(\mathrm{C}_{5} \mathrm{H}_{4}\right), 114.8,126.9\left(\mathrm{C}_{5} \mathrm{H}_{3}\right), 123.2\left(\mathrm{C}_{i p s o}, \mathrm{C}_{5} \mathrm{H}_{4}\right), 144.8$ $\left(\mathrm{C}_{i p s o}, \mathrm{C}_{5} \mathrm{H}_{3}\right)$. MS (EI) $m / z: 496[\mathrm{M}]^{+}(2 \%) ; 318[\mathrm{M}-$ $\left.1,3\left({ }^{t} \mathrm{Bu}\right)_{2} \mathrm{C}_{5} \mathrm{H}_{3}\right]^{+}(100 \%) ; 122\left[\mathrm{C}_{5} \mathrm{H}_{4} \mathrm{SiClMe}_{2}\right]^{+}(21 \%) ; 57$ $\left[\mathrm{Me}_{3} \mathrm{C}\right]^{+}(32 \%)$.

\subsection{Synthesis of $\mathrm{Hf}\left(\eta^{5}-1,3^{t} \mathrm{Bu}_{2} \mathrm{C}_{5} \mathrm{H}_{3}\right)\left(\eta^{5}-\mathrm{C}_{5} \mathrm{H}_{4} \mathrm{SiClMe}_{2}\right) \mathrm{Cl}_{2}(\mathbf{4 c})$}

$\mathrm{Tl}\left(1,3-{ }^{t} \mathrm{Bu}_{2} \mathrm{C}_{5} \mathrm{H}_{3}\right)(0.93 \mathrm{~g}, 2.44 \mathrm{mmol})$ was added to a solution of $\mathrm{Hf}\left(\eta^{5}-\mathrm{C}_{5} \mathrm{H}_{4} \mathrm{SiClMe}_{2}\right) \mathrm{Cl}_{3}(1.08 \mathrm{~g}, 2.44 \mathrm{mmol})$ in toluene $(35 \mathrm{ml})$. The mixture was refluxed with stirring for $14 \mathrm{~h}$ and then filtered to give a solution which was concentrated $(15 \mathrm{ml})$ and cooled to $-30^{\circ} \mathrm{C}$. The resulting solid was washed with hexane $(2 \times 10 \mathrm{ml})$ and recrystallised from toluene-hexane to give $\mathbf{4 c}$ as a white microcrystalline solid $(1.0 \mathrm{~g}, 1.71 \mathrm{mmol}, 70 \%$ yield). Anal. Calc. for $\mathrm{C}_{20} \mathrm{H}_{31} \mathrm{SiCl}_{3} \mathrm{Hf}$ : $\mathrm{C}, 41.11 ; \mathrm{H}, 5.35$. Found: C, 42.00; H, 5.27\%. ${ }^{1} \mathrm{H}-\mathrm{NMR}\left(300 \mathrm{MHz}, \mathrm{C}_{6} \mathrm{D}_{6}\right.$, $\left.25^{\circ} \mathrm{C}\right): \delta 0.66\left(\mathrm{~s}, 6 \mathrm{H}, \mathrm{SiClMe}_{2}\right), 1.18\left(\mathrm{~s}, 18 \mathrm{H},{ }^{t} \mathrm{Bu}\right), 6.03$ $\left(\mathrm{AA}^{\prime}, 2 \mathrm{H}, \mathrm{C}_{5} \mathrm{H}_{3}\right), 6.20\left(\mathrm{AA}^{\prime}, 2 \mathrm{H}, \mathrm{C}_{5} \mathrm{H}_{4}\right), 6.38(\mathrm{~B}, 1 \mathrm{H}$, $\left.\mathrm{C}_{5} \mathrm{H}_{3}\right), 6.53\left(\mathrm{BB}^{\prime}, 2 \mathrm{H}, \mathrm{C}_{5} \mathrm{H}_{4}\right) .\left(300 \mathrm{MHz}, \mathrm{CDCl}_{3}, 25^{\circ} \mathrm{C}\right)$ : $\delta 0.75\left(\mathrm{~s}, 6 \mathrm{H}, \mathrm{SiClMe}_{2}\right), 1.27\left(\mathrm{~s}, 18 \mathrm{H},{ }^{t} \mathrm{Bu}\right), 6.02\left(\mathrm{AA}^{\prime}\right.$, $\left.2 \mathrm{H}, \mathrm{C}_{5} \mathrm{H}_{4}\right), 6.12\left(\mathrm{AA}^{\prime}, 2 \mathrm{H}, \mathrm{C}_{5} \mathrm{H}_{3}\right), 6.33\left(\mathrm{~B}, 1 \mathrm{H}, \mathrm{C}_{5} \mathrm{H}_{3}\right)$, $6.47\left(\mathrm{BB}^{\prime}, 2 \mathrm{H}, \mathrm{C}_{5} \mathrm{H}_{4}\right) .{ }^{13} \mathrm{C}-\left\{{ }^{1} \mathrm{H}\right\} \quad \mathrm{NMR}(125 \mathrm{MHz}$, $\left.\mathrm{CDCl}_{3}, 25^{\circ} \mathrm{C}\right): \delta 3.1\left(\mathrm{SiClMe}_{2}\right), 31.3\left({ }^{t} \mathrm{Bu}\right), 33.8\left(\mathrm{C}_{i p s o}\right.$, $\left.{ }^{t} \mathrm{Bu}\right), 110.0,113.0\left(\mathrm{C}_{5} \mathrm{H}_{4}\right), 113.2,125.5\left(\mathrm{C}_{5} \mathrm{H}_{3}\right), 120.1$ $\left(\mathrm{C}_{\text {ipso }}, \mathrm{C}_{5} \mathrm{H}_{4}\right), 142.6\left(\mathrm{C}_{\text {ipso }}, \mathrm{C}_{5} \mathrm{H}_{3}\right) . \mathrm{MS}(\mathrm{EI}) \mathrm{m} / \mathrm{z}: 584$ $[\mathrm{M}]^{+} \quad(2 \%) ; \quad 549 \quad[\mathrm{M}-\mathrm{Cl}]^{+} \quad(10 \%) ; \quad 407 \quad[\mathrm{M}-$ $\left.1,3\left({ }^{t} \mathrm{Bu}\right) 2 \mathrm{C}_{5} \mathrm{H}_{3}\right]^{+}(100 \%) ; 122\left[\mathrm{C}_{5} \mathrm{H}_{4} \mathrm{SiClMe}_{2}\right]^{+}(15 \%)$; $57\left[\mathrm{Me}_{3} \mathrm{C}\right]^{+}(6 \%)$.

\subsection{Synthesis of $\mathrm{Zr}\left(\eta^{5}-\mathrm{C}_{5} \mathrm{Me}_{5}\right)\left(\eta^{5}-\mathrm{C}_{5} \mathrm{H}_{4} \mathrm{SiClMe}_{2}\right) \mathrm{Cl}_{2}$ (5b)}

$\mathrm{K}\left(\mathrm{C}_{5} \mathrm{Me}_{5}\right)(0.76 \mathrm{~g}, 4.38 \mathrm{mmol})$ was added to a solution of $\mathrm{Zr}\left(\eta^{5}-\mathrm{C}_{5} \mathrm{H}_{4} \mathrm{SiClMe}_{2}\right) \mathrm{Cl}_{3}(1.56 \mathrm{~g}, 4.38 \mathrm{mmol})$ in toluene $(50 \mathrm{ml})$ at $-60^{\circ} \mathrm{C}$. The mixture was warmed to r.t. and stirred for $30 \mathrm{~m}$. After filtration the resulting solution was evaporated under vacuum to dryness. The purple microcrystalline solid was washed with hexane $(2 \times 10 \mathrm{ml})$, recrystallised from toluene-hexane and characterised as 5b (1.0 g, $2.19 \mathrm{mmol}, 50 \%)$. Anal. Calc. for $\mathrm{C}_{17} \mathrm{H}_{25} \mathrm{SiCl}_{3} \mathrm{Zr}: \mathrm{C}$, 44.85; H, 5.53. Found: $\mathrm{C}, 43.85 ; \mathrm{H}$, $5.65 \%$. ${ }^{1} \mathrm{H}-\mathrm{NMR}\left(300 \mathrm{MHz}, \mathrm{C}_{6} \mathrm{D}_{6}, 25^{\circ} \mathrm{C}\right): \delta 0.87(\mathrm{~s}, 6 \mathrm{H}$, $\left.\mathrm{SiClMe}_{2}\right), \quad 1.69 \quad\left(\mathrm{~s}, \quad 15 \mathrm{H}, \quad \mathrm{C}_{5} \mathrm{Me}_{5}\right), \quad 5.62 \quad\left(\mathrm{AA}^{\prime}\right.$, $\left.2 \mathrm{H}, \mathrm{C}_{5} \mathrm{H}_{4}\right), 6.46\left(\mathrm{BB}^{\prime}, 2 \mathrm{H}, \mathrm{C}_{5} \mathrm{H}_{4}\right) .\left(300 \mathrm{MHz}, \mathrm{CDCl}_{3}\right.$, $\left.25^{\circ} \mathrm{C}\right): \delta 0.76\left(\mathrm{~s}, 6 \mathrm{H}, \mathrm{SiClMe}_{2}\right), 2.01\left(\mathrm{~s}, 15 \mathrm{H}, \mathrm{C}_{5} \mathrm{Me}_{5}\right), 6.12$ $\left(\mathrm{AA}^{\prime}, 2 \mathrm{H}, \mathrm{C}_{5} \mathrm{H}_{4}\right), 6.56\left(\mathrm{BB}^{\prime}, 2 \mathrm{H}, \mathrm{C}_{5} \mathrm{H}_{4}\right) .{ }^{13} \mathrm{C}-\left\{{ }^{1} \mathrm{H}\right\} \mathrm{NMR}$ $\left(75 \mathrm{MHz}, \mathrm{C}_{6} \mathrm{D}_{6}, 25^{\circ} \mathrm{C}\right): \delta 3.2\left(\mathrm{SiClMe}_{2}\right), 12.3\left(\mathrm{C}_{5} M e_{5}\right)$, $114.8\left(\mathrm{C}_{5} \mathrm{H}_{4}\right)$ (one of the $\mathrm{C}_{5} \mathrm{H}_{4}$ signal collapsed with the 
solvent signals), $124.5\left(\mathrm{C}_{5} \mathrm{Me}_{5}\right), 125.7\left(\mathrm{C}_{i p s o}, \mathrm{C}_{5} \mathrm{H}_{4}\right)$. MS (EI) $m / z: 454[\mathrm{M}]^{+}(1 \%) ; 320\left[\mathrm{M}-\mathrm{C}_{5} \mathrm{Me}_{5}\right]^{+}(21 \%) ; 135$ $\left[\mathrm{C}_{5} \mathrm{Me}_{5}\right]^{+}(100 \%) ; 122\left[\mathrm{C}_{5} \mathrm{H}_{4} \mathrm{SiMe}_{2}\right]^{+}(28 \%)$.

\subsection{Synthesis of $\mathrm{Hf}\left(\eta^{5}-\mathrm{C}_{5} \mathrm{Me}_{5}\right)\left(\eta^{5}-\mathrm{C}_{5} \mathrm{H}_{4} \mathrm{SiClMe} 2\right) \mathrm{Cl}_{2}$} (5c)

$\mathrm{K}\left(\mathrm{C}_{5} \mathrm{Me}_{5}\right)(0.58 \mathrm{~g}, 3.35 \mathrm{mmol})$ was added to a solution of $\mathrm{Hf}\left(\eta^{5}-\mathrm{C}_{5} \mathrm{H}_{4} \mathrm{SiClMe}_{2}\right) \mathrm{Cl}_{3}(0.58 \mathrm{~g}, 3.35 \mathrm{mmol})$ in toluene at $-60^{\circ} \mathrm{C}$. Following the procedure described above for $\mathbf{5 b}$, a purple microcrystalline solid characterised as $\mathbf{5 c}$ was obtained $(1.0 \mathrm{~g}, 1.85 \mathrm{mmol}, 55 \%)$. Anal. Calc. for $\mathrm{C}_{17} \mathrm{H}_{25} \mathrm{SiCl}_{3} \mathrm{Hf}$ : C, 37.65; H, 4.65. Found: C, 37.63; H, 4.61\%. ${ }^{1} \mathrm{H}-\mathrm{NMR}\left(300 \mathrm{MHz}, \mathrm{C}_{6} \mathrm{D}_{6}, 25^{\circ} \mathrm{C}\right): \delta$ $0.85\left(\mathrm{~s}, 6 \mathrm{H}, \mathrm{SiClMe}_{2}\right), 1.76\left(\mathrm{~s}, 15 \mathrm{H}, \mathrm{C}_{5} \mathrm{Me}_{5}\right), 5.60\left(\mathrm{AA}^{\prime}\right.$, $\left.2 \mathrm{H}, \mathrm{C}_{5} \mathrm{H}_{4}\right), 6.38\left(\mathrm{BB}^{\prime}, 2 \mathrm{H}, \mathrm{C}_{5} \mathrm{H}_{4}\right) .\left(300 \mathrm{MHz}, \mathrm{CDCl}_{3}\right.$, $\left.25^{\circ} \mathrm{C}\right): \delta 0.81\left(\mathrm{~s}, 6 \mathrm{H}, \mathrm{SiClMe}_{2}\right), 1.92\left(\mathrm{~s}, 15 \mathrm{H}, \mathrm{C}_{5} \mathrm{Me}_{5}\right)$, $6.05\left(\mathrm{AA}^{\prime}, 2 \mathrm{H}, \mathrm{C}_{5} \mathrm{H}_{4}\right), 6.60\left(\mathrm{BB}^{\prime}, 2 \mathrm{H}, \mathrm{C}_{5} \mathrm{H}_{4}\right) .{ }^{13} \mathrm{C}-\left\{{ }^{1} \mathrm{H}\right\}$ NMR $\left(75 \mathrm{MHz}, \mathrm{C}_{6} \mathrm{D}_{6}, 25^{\circ} \mathrm{C}\right): \delta 3.6\left(\mathrm{SiClMe}_{2}\right), 15.6$ $\left(\mathrm{C}_{5} \mathrm{Me}_{5}\right), 116.7\left(\mathrm{C}_{5} \mathrm{H}_{4}\right)$ (one of the $\mathrm{C}_{5} \mathrm{H}_{4}$ signal collapsed with the solvent signals), $124.8\left(\mathrm{C}_{\text {ipso }}, \mathrm{C}_{5} \mathrm{H}_{4}\right), 126.8$ $\left(\mathrm{C}_{5} \mathrm{Me}_{5}\right)$. MS (EI) $m / z$ : $541[\mathrm{M}]^{+}(5 \%) ; 407[\mathrm{M}-$ $\begin{array}{lllll}\left.\mathrm{C}_{5} \mathrm{Me}_{5}\right]^{+} \quad(87 \%) ; & 135 & {\left[\mathrm{C}_{5} \mathrm{Me}_{5}\right]^{+} \quad(36 \%) ;} & 122\end{array}$ $\left[\mathrm{C}_{5} \mathrm{H}_{4} \mathrm{SiMe}_{2}\right]^{+}(100 \%)$.

\subsection{Synthesis of $\mathrm{Hf}\left(\mathrm{C}_{5} \mathrm{H}_{5}\right)\left(\mathrm{C}_{5} \mathrm{H}_{4} \mathrm{SiClMe}_{2}\right) \mathrm{Cl}_{2}$ (6c)}

$\mathrm{Tl}\left(\mathrm{C}_{5} \mathrm{H}_{5}\right)(0.95 \mathrm{~g}, 3.53 \mathrm{mmol})$ was added to a solution of $\mathrm{Hf}\left(\mathrm{C}_{5} \mathrm{H}_{4} \mathrm{SiMe}_{2} \mathrm{Cl}\right) \mathrm{Cl}_{3}(1.56 \mathrm{~g}, 3.53 \mathrm{mmol})$ in toluene at $-78^{\circ} \mathrm{C}$. The mixture was warmed to r.t. and stirred for $12 \mathrm{~h}$. After filtration, the resulting solution was concentrated and cooled to $-30^{\circ} \mathrm{C}$ to give a white solid which was washed with hexane, recrystallised from toluene-hexane and characterised as $6(1.0 \mathrm{~g}, 2.12$ mmol, $60 \%$ yield). Anal. Calc. for $\mathrm{C}_{12} \mathrm{H}_{15} \mathrm{SiCl}_{3} \mathrm{Hf}$ : $\mathrm{C}$, 30.55; H, 3.20. Found: C, 31.35; H, 3.47\%. ${ }^{1} \mathrm{H}-\mathrm{NMR}$ $\left(300 \mathrm{MHz}, \mathrm{C}_{6} \mathrm{D}_{6}, 25^{\circ} \mathrm{C}\right): \delta 0.66\left(\mathrm{~s}, 6 \mathrm{H}, \mathrm{SiMe}_{2} \mathrm{Cl}\right), 5.71$ $\left(\mathrm{AA}^{\prime}, 2 \mathrm{H}, \mathrm{C}_{5} \mathrm{H}_{4}\right), 5.86\left(\mathrm{~s}, 5 \mathrm{H}, \mathrm{C}_{5} \mathrm{H}_{5}\right), 6.27\left(\mathrm{BB}^{\prime}, 2 \mathrm{H}\right.$, $\left.\mathrm{C}_{5} \mathrm{H}_{4}\right) .\left(300 \mathrm{MHz}, \mathrm{CDCl}_{3}, 25^{\circ} \mathrm{C}\right): \delta 0.72(\mathrm{~s}, 6 \mathrm{H}$, $\left.\mathrm{SiMe}_{2} \mathrm{Cl}\right), 6.39\left(\mathrm{~s}, 5 \mathrm{H}, \mathrm{C}_{5} \mathrm{H}_{5}\right), 6.48\left(\mathrm{AA}^{\prime}, 2 \mathrm{H}, \mathrm{C}_{5} \mathrm{H}_{4}\right)$, $6.70\left(\mathrm{BB}^{\prime}, \quad 2 \mathrm{H}, \mathrm{C}_{5} \mathrm{H}_{4}\right) .{ }^{13} \mathrm{C}-\left\{{ }^{1} \mathrm{H}\right\} \quad \mathrm{NMR}(75 \mathrm{MHz}$, $\left.\mathrm{CDCl}_{3}, 25^{\circ} \mathrm{C}\right): \delta 3.2\left(\mathrm{SiMe}_{2} \mathrm{Cl}\right), 115.8,124.2\left(\mathrm{C}_{2}-\mathrm{C}_{5}\right.$, $\left.\mathrm{C} \mathrm{H}_{4}\right), 119.3\left(\mathrm{C}_{i p s o}, \mathrm{C}_{5} \mathrm{H}_{4}\right) 114.9\left(\mathrm{C}_{5} \mathrm{H}_{5}\right)$. MS (EI) $\mathrm{m} / z$ : $472[\mathrm{M}]^{+}(2 \%) ; 437[\mathrm{M}-\mathrm{Cl}]^{+}(26 \%) ; 407\left[\mathrm{M}-\mathrm{C}_{5} \mathrm{H}_{5}\right]^{+}$ $(66 \%) ; \quad 315 \quad\left[\mathrm{M}-\mathrm{C}_{5} \mathrm{H}_{4} \mathrm{SiMe}_{2} \mathrm{Cl}\right]^{+} \quad(14 \%) ; \quad 122$ $\left[\mathrm{C}_{5} \mathrm{H}_{4} \mathrm{SiMe}_{2}\right]^{+}(100 \%)$.

\subsection{Synthesis of \\ $\mathrm{Ti}\left(\eta^{5}-1,3^{t} \mathrm{Bu}_{2} \mathrm{C}_{5} \mathrm{H}_{3}\right)\left(\eta^{5}-\mathrm{C}_{5} \mathrm{H}_{4} \mathrm{SiMe}_{2} \mathrm{NH}^{t} \mathrm{Bu}\right) \mathrm{Cl}_{2}$ (7a)}

$\mathrm{LiNH}^{t} \mathrm{Bu}(0.25 \mathrm{~g}, 3.14 \mathrm{mmol})$ was added to a solution of $\mathrm{Ti}\left(1,3-{ }^{t} \mathrm{Bu}_{2} \mathrm{C}_{5} \mathrm{H}_{3}\right)\left(\eta^{5}-\mathrm{C}_{5} \mathrm{H}_{4} \mathrm{SiClMe}_{2}\right) \mathrm{Cl}_{2}(1.43 \mathrm{~g}$, $3.14 \mathrm{mmol})$ in toluene $(50 \mathrm{ml})$. The mixture was warmed at $50-60^{\circ} \mathrm{C}$ with stirring for $6 \mathrm{~h}$. The solution was filtered, concentrated $(10 \mathrm{ml})$ and cooled at $-30^{\circ} \mathrm{C}$ to give a red solid which was dried under reduced pressure, recrystallised from toluene-hexane and characterised as 7a $(1.0 \mathrm{~g}, 2.04 \mathrm{mmol}, 65 \%$ yield $)$. Anal. Calc. for $\mathrm{C}_{24} \mathrm{H}_{41} \mathrm{SiNCl}_{2} \mathrm{Ti}: \mathrm{C}, 58.77 ; \mathrm{H}, 8.43 ; \mathrm{N}, 2.86$. Found: C, 59.67; H, 8.78; N, 2.95\%. ${ }^{1} \mathrm{H}-\mathrm{NMR}(300$ $\left.\mathrm{MHz}, \mathrm{C}_{6} \mathrm{D}_{6}, 25^{\circ} \mathrm{C}\right): \delta 0.6\left(\mathrm{~s}, 6 \mathrm{H}, \mathrm{SiMe}_{2}\right), 1.16(\mathrm{~s}, 9 \mathrm{H}$, $\left.{ }^{t} \mathrm{BuN}\right), 1.18\left(\mathrm{~s}, 18 \mathrm{H},{ }^{t} \mathrm{Bu}\right), 5.87\left(\mathrm{AA}^{\prime}, 2 \mathrm{H}, \mathrm{C}_{5} \mathrm{H}_{3}\right), 6.12$ $\left(\mathrm{AA}^{\prime}, 2 \mathrm{H}, \mathrm{C}_{5} \mathrm{H}_{4}\right), 6.5\left(\mathrm{~B}, 1 \mathrm{H}, \mathrm{C}_{5} \mathrm{H}_{3}\right), 6.70\left(\mathrm{BB}^{\prime}, 2 \mathrm{H}\right.$, $\mathrm{C}_{5} \mathrm{H}_{4}$ ); the amino proton signal was not observed. (300 $\left.\mathrm{MHz}, \mathrm{CDCl}_{3}, 25^{\circ} \mathrm{C}\right): \delta 0.39$ (s, $\left.6 \mathrm{H}, \mathrm{SiMe}_{2}\right), 1.08(\mathrm{~s}, 9 \mathrm{H}$, $\left.{ }^{t} \mathrm{BuN}\right), 1.24\left(\mathrm{~s}, 18 \mathrm{H},{ }^{t} \mathrm{Bu}\right), 6.12\left(\mathrm{AA}^{\prime}, 2 \mathrm{H}, \mathrm{C}_{5} \mathrm{H}_{4}\right), 6.30$ $\left(\mathrm{AA}^{\prime}, 2 \mathrm{H}, \mathrm{C}_{5} \mathrm{H}_{3}\right), 6.61\left(\mathrm{~B}, 1 \mathrm{H}, \mathrm{C}_{5} \mathrm{H}_{3}\right), 6.75\left(\mathrm{BB}^{\prime}, 2 \mathrm{H}\right.$, $\mathrm{C}_{5} \mathrm{H}_{4}$ ); the amino proton signal was not observed. ${ }^{13} \mathrm{C}-\left\{{ }^{1} \mathrm{H}\right\}$ NMR $\left(75 \mathrm{MHz}, \mathrm{C}_{6} \mathrm{D}_{6}, 25^{\circ} \mathrm{C}\right): \delta 2.7\left(\mathrm{SiMe}_{2}\right)$, $30.9\left({ }^{t} \mathrm{Bu}\right), 32.7\left({ }^{t} \mathrm{BuN}\right), 35.0\left(\mathrm{C}_{i p s o},{ }^{t} \mathrm{Bu}\right), 49.6\left(\mathrm{C}_{\text {ipso }}\right.$, $\left.{ }^{t} \mathrm{BuN}\right)$, 113.7, $117.5\left(\mathrm{C}_{5} \mathrm{H}_{4}\right), 120.3,131.9\left(\mathrm{C}_{5} \mathrm{H}_{3}\right), 133.5$ $\left(\mathrm{C}_{\text {ipso }}, \mathrm{C}_{5} \mathrm{H}_{3}\right), 150.4\left(\mathrm{C}_{\text {ipso }}, \mathrm{C}_{5} \mathrm{H}_{4}\right) . \mathrm{MS}$ (EI) $\mathrm{m} / z: 419$ $\left[\mathrm{M}-\mathrm{NH}^{t} \mathrm{Bu}\right]^{+}(6 \%) ; 312\left[\mathrm{M}-1,3\left({ }^{t} \mathrm{Bu}\right)_{2} \mathrm{C}_{5} \mathrm{H}_{3}\right]^{+}(9 \%)$; $256 \quad\left[\mathrm{M}-1,3\left({ }^{t} \mathrm{Bu}\right)_{2} \mathrm{C}_{5} \mathrm{H}_{3}{ }^{-}{ }^{t} \mathrm{Bu}\right]^{+} \quad(19 \%) ; \quad 122$ $\left[\mathrm{C}_{5} \mathrm{H}_{4} \mathrm{SiMe}_{2}\right]^{+}(25 \%) ; 57\left[\mathrm{Me}_{3} \mathrm{C}\right]^{+}(100 \%)$. IR (KBr): $v(\mathrm{~N}-\mathrm{H})=3375 \mathrm{~cm}^{-1}$.

\subsection{Synthesis of \\ $\mathrm{Zr}\left(\eta^{5}-1,3^{t} \mathrm{Bu}_{2} \mathrm{C}_{5} \mathrm{H}_{3}\right)\left(\eta^{5}-\mathrm{C}_{5} \mathrm{H}_{4} \mathrm{SiMe}_{2} \mathrm{NH}^{t} \mathrm{Bu}\right) \mathrm{Cl}_{2}$ (7b)}

Following the procedure described for the synthesis of $7 \mathbf{a}, \mathrm{LiNH}^{t} \mathrm{Bu}(0.22 \mathrm{~g}, 2.79 \mathrm{mmol})$ and $\mathrm{Zr}(1,3-$ $\left.{ }^{t} \mathrm{Bu}_{2} \mathrm{C}_{5} \mathrm{H}_{3}\right)\left(\eta^{5}-\mathrm{C}_{5} \mathrm{H}_{4} \mathrm{SiClMe}_{2}\right) \mathrm{Cl}_{2}(1.38 \mathrm{~g}, 2.79 \mathrm{mmol})$ were reacted to give a white microcrystalline solid characterised as $7 \mathbf{b}(1.0 \mathrm{~g}, 1.87 \mathrm{mmol}, 67 \%$ yield $)$. Anal. Calc. for $\mathrm{C}_{24} \mathrm{H}_{41} \mathrm{SiNCl}_{2} \mathrm{Zr}$ : C, 54.22; H, 7.78; N, 2.64 . Found: C, 55.31; H, 7.95; N, 2.95\%. ${ }^{1} \mathrm{H}-\mathrm{NMR}(300$ $\left.\mathrm{MHz}, \mathrm{C}_{6} \mathrm{D}_{6}, 25^{\circ} \mathrm{C}\right): \delta 0.56\left(\mathrm{~s}, 6 \mathrm{H}, \mathrm{SiMe}_{2}\right), 1.14(\mathrm{~s}, 9 \mathrm{H}$, $\left.{ }^{t} \mathrm{BuN}\right), 1.20\left(\mathrm{~s}, 18 \mathrm{H},{ }^{t} \mathrm{Bu}\right), 5.9\left(\mathrm{AA}^{\prime}, 2 \mathrm{H}, \mathrm{C}_{5} \mathrm{H}_{3}\right), 6.13$ $\left(\mathrm{AA}^{\prime}, 2 \mathrm{H}, \mathrm{C}_{5} \mathrm{H}_{4}\right), 6.32\left(\mathrm{~B}, 1 \mathrm{H}, \mathrm{C}_{5} \mathrm{H}_{3}\right), 6.65\left(\mathrm{BB}^{\prime}, 2 \mathrm{H}\right.$, $\mathrm{C}_{5} \mathrm{H}_{4}$ ); the amino proton signal was not observed. (300 $\mathrm{MHz}, \mathrm{CDCl}_{3}, 25^{\circ} \mathrm{C}$ ): $\delta 0.37$ (s, $\left.6 \mathrm{H}, \mathrm{SiMe}_{2}\right), 1.08$ (s, 9H, $\left.{ }^{t} \mathrm{BuN}\right), 1.23\left(\mathrm{~s}, 18 \mathrm{H},{ }^{t} \mathrm{Bu}\right), 6.17\left(\mathrm{AA}^{\prime}, 2 \mathrm{H}, \mathrm{C}_{5} \mathrm{H}_{3}\right), 6.49$ $\left(\mathrm{AA}^{\prime}, 2 \mathrm{H}, \mathrm{C}_{5} \mathrm{H}_{4}\right), 6.55\left(\mathrm{~B}, 1 \mathrm{H}, \mathrm{C}_{5} \mathrm{H}_{3}\right), 6.71\left(\mathrm{BB}^{\prime}, 2 \mathrm{H}\right.$, $\mathrm{C}_{5} \mathrm{H}_{4}$ ); the amino proton signal was not observed. ${ }^{13} \mathrm{C}-\left\{{ }^{1} \mathrm{H}\right\}$ NMR $\left(75 \mathrm{MHz}, \mathrm{C}_{6} \mathrm{D}_{6}, 25^{\circ} \mathrm{C}\right): \delta 3.0\left(\mathrm{SiMe}_{2}\right)$, $33.4\left({ }^{t} \mathrm{Bu}\right), 35.6\left({ }^{t} \mathrm{BuN}\right), 32.6\left(\mathrm{C}_{i p s o},{ }^{t} \mathrm{Bu}\right), 51.7\left(\mathrm{C}_{i p s o}\right.$, $\left.{ }^{t} \mathrm{BuN}\right), 110.8,115.6\left(\mathrm{C}_{5} \mathrm{H}_{4}\right), 123.6,134.5\left(\mathrm{C}_{5} \mathrm{H}_{3}\right), 135.6$ $\left(\mathrm{C}_{\text {ipso }}, \mathrm{C}_{5} \mathrm{H}_{3}\right), 156.6\left(\mathrm{C}_{\text {ipso }}, \mathrm{C}_{5} \mathrm{H}_{4}\right) . \mathrm{MS}$ (EI) $\mathrm{m} / z: 462$ $\left[\mathrm{M}-\mathrm{NH}^{t} \mathrm{Bu}\right]^{+}(10 \%) ; 357\left[\mathrm{M}-1,3\left({ }^{t} \mathrm{Bu}\right)_{2} \mathrm{C}_{5} \mathrm{H}_{3}\right]^{+}(7 \%)$; $300 \quad\left[\mathrm{M}-1,3\left({ }^{t} \mathrm{Bu}\right)_{2} \mathrm{C}_{5} \mathrm{H}_{3}{ }^{-}{ }^{t} \mathrm{Bu}\right]^{+} \quad(12 \%) ; \quad 122$ $\left[\mathrm{C}_{5} \mathrm{H}_{4} \mathrm{SiMe}_{2}\right]^{+}(35 \%) ; 57\left[\mathrm{Me}_{3} \mathrm{C}\right]^{+}(100 \%)$. IR (KBr): $v(\mathrm{~N}-\mathrm{H})=3379 \mathrm{~cm}^{-1}$.

\subsection{Synthesis of \\ $\mathrm{Hf}\left(\eta^{5}-1,3^{t} \mathrm{Bu}_{2} \mathrm{C}_{5} \mathrm{H}_{3}\right)\left(\eta^{5}-\mathrm{C}_{5} \mathrm{H}_{4} \mathrm{SiMe}_{2} \mathrm{NH}^{t} \mathrm{Bu}\right) \mathrm{Cl}_{2}(\mathbf{7 c})$}

Following the procedure described for the synthesis of $7 \mathbf{a}, \mathrm{LiNH}^{t} \mathrm{Bu}(0.21 \mathrm{~g}, 2.79 \mathrm{mmol})$ and $\mathrm{Hf}(1,3-$ $\left.{ }^{t} \mathrm{Bu}_{2} \mathrm{C}_{5} \mathrm{H}_{3}\right)\left(\eta^{5}-\mathrm{C}_{5} \mathrm{H}_{4} \mathrm{SiClMe}_{2}\right) \mathrm{Cl}_{2}(1.56 \mathrm{~g}, 2.23 \mathrm{mmol})$ were reacted to give a white microcrystalline solid characterised as 7c $(1.0 \mathrm{~g}, 1.61 \mathrm{mmol}, 58 \%$ yield $)$. Anal. 
Calc. for $\mathrm{C}_{24} \mathrm{H}_{41} \mathrm{SiNCl}_{2} \mathrm{Hf}$ : C, 46.41; H, 6.65; N, 2.26. Found: C, 47.50; H, 6.87; N, 2.53\%. ${ }^{1} \mathrm{H}-\mathrm{NMR}(300 \mathrm{MHz}$, $\left.\mathrm{C}_{6} \mathrm{D}_{6}, 25^{\circ} \mathrm{C}\right): \delta 0.62\left(\mathrm{~s}, 6 \mathrm{H}, \mathrm{SiMe}_{2}\right), 1.1\left(\mathrm{~s}, 9 \mathrm{H},{ }^{t} \mathrm{BuN}\right), 1.4$ $\left(\mathrm{s}, 18 \mathrm{H},{ }^{t} \mathrm{Bu}\right), 5.83\left(\mathrm{AA}^{\prime}, 2 \mathrm{H}, \mathrm{C}_{5} \mathrm{H}_{3}\right), 6.23\left(\mathrm{AA}^{\prime}, 2 \mathrm{H}\right.$, $\left.\mathrm{C}_{5} \mathrm{H}_{4}\right), 6.42\left(\mathrm{~B}, 1 \mathrm{H}, \mathrm{C}_{5} \mathrm{H}_{3}\right), 6.73\left(\mathrm{BB}^{\prime}, 2 \mathrm{H}, \mathrm{C}_{5} \mathrm{H}_{4}\right)$; the amino proton signal was not observed. (300 $\mathrm{MHz}$, $\left.\mathrm{CDCl}_{3}, 25^{\circ} \mathrm{C}\right): \delta 0.35\left(\mathrm{~s}, 6 \mathrm{H}, \mathrm{SiMe}_{2}\right), 1.07\left(\mathrm{~s}, 9 \mathrm{H},{ }^{t} \mathrm{BuN}\right)$, $1.20\left(\mathrm{~s}, 18 \mathrm{H},{ }^{t} \mathrm{Bu}\right), 6.41\left(\mathrm{AA}^{\prime}, 2 \mathrm{H}, \mathrm{C}_{5} \mathrm{H}_{3}\right), 6.61\left(\mathrm{AA}^{\prime}\right.$, $\left.2 \mathrm{H}, \mathrm{C}_{5} \mathrm{H}_{4}\right), 6.57\left(\mathrm{~B}, 1 \mathrm{H}, \mathrm{C}_{5} \mathrm{H}_{3}\right), 6.80\left(\mathrm{BB}^{\prime}, 2 \mathrm{H}, \mathrm{C}_{5} \mathrm{H}_{4}\right)$; the amino proton signal was not observed. ${ }^{13} \mathrm{C}-\left\{{ }^{1} \mathrm{H}\right\}$ NMR $\left(75 \mathrm{MHz}, \mathrm{C}_{6} \mathrm{D}_{6}, 25^{\circ} \mathrm{C}\right): \delta 2.5\left(\mathrm{SiMe}_{2}\right), 31.6$ $\left({ }^{t} \mathrm{Bu}\right), 37.8\left({ }^{t} \mathrm{BuN}\right), 34.3\left(\mathrm{C}_{\text {ipso }},{ }^{t} \mathrm{Bu}\right), 50.9\left(\mathrm{C}_{\text {ipso }},{ }^{t} \mathrm{BuN}\right)$, 112.6, $116.8\left(\mathrm{C}_{5} \mathrm{H}_{4}\right), 125.3,138.6\left(\mathrm{C}_{5} \mathrm{H}_{3}\right), 138.3\left(\mathrm{C}_{\text {ipso }}\right.$, $\left.\mathrm{C}_{5} \mathrm{H}_{3}\right), 150.5\left(\mathrm{C}_{i p s o}, \mathrm{C}_{5} \mathrm{H}_{4}\right)$. MS (EI) $m / z: 549[\mathrm{M}-$ $\left.\mathrm{NH}^{t} \mathrm{Bu}\right]^{+}(13 \%) ; 444\left[\mathrm{M}-1,3\left({ }^{t} \mathrm{Bu}\right)_{2} \mathrm{C}_{5} \mathrm{H}_{3}\right]^{+}(5 \%) ; 387$ $\left[\mathrm{M}-1,3\left({ }^{t} \mathrm{Bu}\right)_{2} \mathrm{C}_{5} \mathrm{H}_{3}{ }^{-}{ }^{t} \mathrm{Bu}\right]^{+} \quad(23 \%) ; 122 \quad\left[\mathrm{C}_{5} \mathrm{H}_{4} \mathrm{SiMe}_{2}\right]^{+}$ $(32 \%) ; 57\left[\mathrm{Me}_{3} \mathrm{C}\right]^{+}(100 \%)$. IR $(\mathrm{KBr}): v(\mathrm{~N}-\mathrm{H})=3379$ $\mathrm{cm}^{-1}$.

\subsection{Synthesis of}

$\mathrm{Ti}\left(\eta^{5}-1,3^{t} \mathrm{Bu}_{2} \mathrm{C}_{5} \mathrm{H}_{3}\right)\left(\eta^{5}-\mathrm{C}_{5} \mathrm{H}_{4} \mathrm{SiMe}_{2}-\eta-N^{t} \mathrm{Bu}\right) \mathrm{Cl}_{2}(\mathbf{8} \boldsymbol{a})$

$\mathrm{LiNH}^{t} \mathrm{Bu}(0.43 \mathrm{~g}, 5.50 \mathrm{mmol})$ was added to a solution of $\mathrm{Ti}\left(1,3-{ }^{\mathrm{t}} \mathrm{Bu}_{2} \mathrm{C}_{5} \mathrm{H}_{3}\right)\left(\eta^{5}-\mathrm{C}_{5} \mathrm{H}_{4} \mathrm{SiClMe}_{2}\right) \mathrm{Cl}_{2}(1.24 \mathrm{~g}, 2.75$ $\mathrm{mmol})$ in toluene $(50 \mathrm{ml})$ at $-78^{\circ} \mathrm{C}$. The mixture was warmed to r.t. and stirred for $8 \mathrm{~h}$. After filtration, the solvent was removed under vacuum to dryness to obtain a red oil. Extraction with cold hexane and cooling to $-30^{\circ} \mathrm{C}$ gave a red microcrystalline solid characterised as 8a (1.0 g, $2.20 \mathrm{mmol}, 80 \%$ yield). Anal. Calc. for $\mathrm{C}_{24} \mathrm{H}_{40}$ SiNClTi: C, 63.49; H, 8.88; N, 3.09. Found: C, 63.38; H, 8.90; N, 3.20\%. ${ }^{1} \mathrm{H}-\mathrm{NMR}\left(300 \mathrm{MHz}, \mathrm{C}_{6} \mathrm{D}_{6}\right.$, $25^{\circ} \mathrm{C}$ ): $\delta 0.32$ (s, 3H, SiMe), 0.67 (s, 3H, SiMe); 1.05 (s, $\left.9 \mathrm{H},{ }^{t} \mathrm{Bu}\right), 1.27\left(\mathrm{~s}, 9 \mathrm{H},{ }^{t} \mathrm{Bu}\right), 1.41\left(\mathrm{~s}, 9 \mathrm{H},{ }^{t} \mathrm{Bu}\right), 5.69,5.71$, 6.19, 6.42, 6.51, 6.87, $7.19\left(\mathrm{C}_{5} \mathrm{H}_{3}, \mathrm{C}_{5} \mathrm{H}_{4}\right)$. (300 MHz, $\mathrm{CDCl}_{3}, 25^{\circ} \mathrm{C}$ ): $\delta 0.35$ (s, 3H, SiMe), 0.59 (s, 3H, SiMe), $1.17\left(\mathrm{~s}, 9 \mathrm{H},{ }^{t} \mathrm{Bu}\right), 1.23\left(\mathrm{~s}, 9 \mathrm{H},{ }^{t} \mathrm{Bu}\right), 1.40\left(\mathrm{~s}, 9 \mathrm{H},{ }^{t} \mathrm{Bu}\right), 5.76$, 6.04, 6.23, 6.27, 6.84, 6.88, $6.95\left(\mathrm{C}_{5} \mathrm{H}_{3}, \mathrm{C}_{5} \mathrm{H}_{4}\right) .{ }^{13} \mathrm{C}-\left\{{ }^{1} \mathrm{H}\right\}$ NMR (75 MHz, $\left.\mathrm{CDCl}_{3}, 25^{\circ} \mathrm{C}\right): \delta 1.7(\mathrm{SiMe}), 4.5$ (SiMe), $31.4\left({ }^{t} \mathrm{Bu}\right), 31.5\left({ }^{t} \mathrm{Bu}\right), 34.1\left({ }^{t} \mathrm{BuN}\right), 33.6\left(\mathrm{C}_{i p s o},{ }^{t} \mathrm{Bu}\right), 33.9$ $\left(\mathrm{C}_{i p s o},{ }^{t} \mathrm{Bu}\right), 66.3\left(\mathrm{C}_{i p s o},{ }^{t} \mathrm{BuN}\right), 107.2,112.0,113.0,118.4$, $118.8,121.3,135.3\left(\mathrm{C}_{5} \mathrm{H}_{3}, \mathrm{C}_{5} \mathrm{H}_{4}\right), 109.8,134.4,141.6$ $\left(\mathrm{C}_{i p s o}, \mathrm{C}_{5} \mathrm{H}_{4}, \mathrm{C}_{5} \mathrm{H}_{3}\right)$. MS (EI) $m / z: 453[\mathrm{M}]^{+}(3 \%) ; 276$ $\left[\mathrm{M}-1,3\left({ }^{t} \mathrm{Bu}\right)_{2} \mathrm{C}_{5} \mathrm{H}_{3}\right]^{+}(100 \%) ; 261\left[\mathrm{M}-1,3\left({ }^{t} \mathrm{Bu}\right)_{2} \mathrm{C}_{5} \mathrm{H}_{3}-\right.$ $\left.\mathrm{CH}_{3}\right]^{+} \quad(51 \%) ; \quad 220 \quad\left[\mathrm{M}-1,3\left({ }^{t} \mathrm{Bu}\right)_{2} \mathrm{C}_{5} \mathrm{H}_{3}-\mathrm{CH}_{3}{ }^{-}{ }^{t} \mathrm{Bu}\right]^{+}$ $(40 \%)$.

\subsection{Synthesis of}

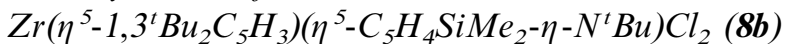

Following the procedure described for the synthesis of $8 \mathbf{a}, \mathrm{LiNH}^{t} \mathrm{Bu}(0.37 \mathrm{~g}, 4.67 \mathrm{mmol})$ and $\mathrm{Zr}(1,3-$ $\left.{ }^{t} \mathrm{Bu}_{2} \mathrm{C}_{5} \mathrm{H}_{3}\right)\left(\eta^{5}-\mathrm{C}_{5} \mathrm{H}_{4} \mathrm{SiClMe}_{2}\right) \mathrm{Cl}_{2}(1.11 \mathrm{~g}, 2.23 \mathrm{mmol})$ were reacted to give a white microcrystalline solid characterised as $\mathbf{8 b}$ (1.0 g, $2.01 \mathrm{mmol}, 90 \%$ yield). Anal. Calc. for $\mathrm{C}_{24} \mathrm{H}_{40} \mathrm{SiNClZr}$ : C, 57.96; H, 8.11; N, 2.82 . Found: C, 57.76; H, 8.07; N, 2.82\%. ${ }^{1} \mathrm{H}-\mathrm{NMR}(300 \mathrm{MHz}$, $\mathrm{C}_{6} \mathrm{D}_{6}, 25^{\circ} \mathrm{C}$ ): $\delta 0.38$ (s, 3H, SiMe), 0.63 (s, 3H, SiMe); $1.13\left(\mathrm{~s}, 9 \mathrm{H},{ }^{t} \mathrm{Bu}\right), 1.28\left(\mathrm{~s}, 9 \mathrm{H},{ }^{t} \mathrm{Bu}\right), 1.32\left(\mathrm{~s}, 9 \mathrm{H},{ }^{t} \mathrm{Bu}\right), 5.81$, 5.89, 6.21, 6.28, 6.33, 6.63, $6.89\left(\mathrm{C}_{5} \mathrm{H}_{3}, \mathrm{C}_{5} \mathrm{H}_{4}\right)$. (300 MHz, $\mathrm{CDCl}_{3}, 25^{\circ} \mathrm{C}$ ): $\delta 0.38$ (s, 3H, SiMe), 0.54 (s, 3H, SiMe), $1.21\left(\mathrm{~s}, 9 \mathrm{H},{ }^{t} \mathrm{Bu}\right), 1.28\left(\mathrm{~s}, 9 \mathrm{H},{ }^{t} \mathrm{Bu}\right), 1.29\left(\mathrm{~s}, 9 \mathrm{H},{ }^{t} \mathrm{Bu}\right), 5.94$, 6.08, 6.12, 6.28, 6.64, 6.71, $6.89\left(\mathrm{C}_{5} \mathrm{H}_{3}, \mathrm{C}_{5} \mathrm{H}_{4}\right) .{ }^{13} \mathrm{C}-\left\{{ }^{1} \mathrm{H}\right\}$ NMR (75 MHz, $\left.\mathrm{CDCl}_{3}, 25^{\circ} \mathrm{C}\right): \delta 1.8(\mathrm{SiMe}), 4.8(\mathrm{SiMe})$, $31.2\left({ }^{t} \mathrm{Bu}\right), 31.9\left({ }^{t} \mathrm{Bu}\right), 34.5\left({ }^{t} \mathrm{BuN}\right), 33.2\left(\mathrm{C}_{\text {ipso }},{ }^{t} \mathrm{Bu}\right), 33.4$ $\left(\mathrm{C}_{i p s o},{ }^{t} \mathrm{Bu}\right), 59.3\left(\mathrm{C}_{i p s o},{ }^{t} \mathrm{BuN}\right), 108.9,109.8,114.2,117.0$, $118.2,128.5,\left(\mathrm{C}_{5} \mathrm{H}_{3}, \mathrm{C}_{5} \mathrm{H}_{4}\right), 111.7,135.1,139.6\left(\mathrm{C}_{\text {ipso }}\right.$, $\left.\mathrm{C}_{5} \mathrm{H}_{4}, \mathrm{C}_{5} \mathrm{H}_{3}\right)$. MS (EI) $m / z: 495[\mathrm{M}]^{+}(2 \%) ; 480[\mathrm{M}-$ $\left.\mathrm{CH}_{3}\right]^{+}(100 \%) ; 423\left[\mathrm{M}-{ }^{t} \mathrm{Bu}-\mathrm{CH}_{3}\right]^{+}(19 \%) ; 302[\mathrm{M}-$ $\left.\mathrm{CH}_{3}-1,3\left({ }^{t} \mathrm{Bu}\right)_{2} \mathrm{C}_{5} \mathrm{H}_{3}\right]^{+} \quad(45 \%) ; \quad 245 \quad\left[\mathrm{M}-1,3\left({ }^{t} \mathrm{Bu}\right)_{2}{ }^{-}\right.$ $\left.\mathrm{C}_{5} \mathrm{H}_{3}-\mathrm{CH}_{3}{ }^{-}{ }^{t} \mathrm{Bu}\right]^{+}(72 \%)$.

\subsection{Synthesis of \\ $\mathrm{Hf}\left(\eta^{5}-1,3^{t} \mathrm{Bu}_{2} \mathrm{C}_{5} \mathrm{H}_{3}\right)\left(\eta^{5}-\mathrm{C}_{5} \mathrm{H}_{4} \mathrm{SiMe}_{2}-\eta-N^{t} \mathrm{Bu}\right) \mathrm{Cl}_{2}(\boldsymbol{8 c})$}

Following the procedure described for the synthesis of 8a, $\quad \mathrm{LiNH}^{t} \mathrm{Bu}(0.31 \mathrm{~g}, \quad 3.93 \mathrm{mmol})$ and $\operatorname{Hf}(1,3-$ $\left.{ }^{t} \mathrm{Bu}_{2} \mathrm{C}_{5} \mathrm{H}_{3}\right)\left(\eta^{5}-\mathrm{C}_{5} \mathrm{H}_{4} \mathrm{SiClMe}_{2}\right) \mathrm{Cl}_{2}(1.15 \mathrm{~g}, 1.97 \mathrm{mmol})$ were reacted to give a white microcrystalline solid characterised as $8 \mathrm{c}(1.0 \mathrm{~g}, 1.71 \mathrm{mmol}, 87 \%$ yield $)$. Anal. Calc. for $\mathrm{C}_{24} \mathrm{H}_{40}$ SiNClHf: C, 49.31; H, 6.90; N, 2.40. Found: C, 48.83; H, 6.98; N, 2.50\%. ${ }^{1} \mathrm{H}-\mathrm{NMR}\left(300 \mathrm{MHz}, \mathrm{C}_{6} \mathrm{D}_{6}\right.$, $25^{\circ} \mathrm{C}$ ): $\delta 0.40$ (s, 3H, SiMe), 0.63 (s, 3H, SiMe); 1.16 (s, $\left.9 \mathrm{H},{ }^{t} \mathrm{Bu}\right), 1.29\left(\mathrm{~s}, 9 \mathrm{H},{ }^{t} \mathrm{Bu}\right), 1.32\left(\mathrm{~s}, 9 \mathrm{H},{ }^{t} \mathrm{Bu}\right), 5.80,6.14$, 6.17, 6.29, 6.58, $6.78\left(\mathrm{C}_{5} \mathrm{H}_{3}, \mathrm{C}_{5} \mathrm{H}_{4}\right) .\left(300 \mathrm{MHz}, \mathrm{CDCl}_{3}\right.$, $25^{\circ} \mathrm{C}$ ): $\delta 0.38$ (s, 3H, SiMe), 0.55 (s, 3H, SiMe), 1.22 (s, $\left.9 \mathrm{H},{ }^{t} \mathrm{Bu}\right), 1.28\left(\mathrm{~s}, 9 \mathrm{H},{ }^{t} \mathrm{Bu}\right), 1.31\left(\mathrm{~s}, 9 \mathrm{H},{ }^{t} \mathrm{Bu}\right), 5.86,5.97$, 6.10, 6.24, 6.53, 6.63, $6.65\left(\mathrm{C}_{5} \mathrm{H}_{3}, \mathrm{C}_{5} \mathrm{H}_{4}\right) .{ }^{13} \mathrm{C}-\left\{{ }^{1} \mathrm{H}\right\} \mathrm{NMR}$ (75 MHz, $\left.\mathrm{CDCl}_{3}, 25^{\circ} \mathrm{C}\right): \delta 2.0(\mathrm{SiMe}), 4.9$ (SiMe), 31.6 $\left({ }^{t} \mathrm{Bu}\right), 31.9\left({ }^{t} \mathrm{Bu}\right), 34.8\left({ }^{t} \mathrm{BuN}\right), 33.1\left(\mathrm{C}_{i p s o},{ }^{t} \mathrm{Bu}\right), 33.3\left(\mathrm{C}_{i p s o}\right.$, $\left.{ }^{t} \mathrm{Bu}\right), 58.3\left(\mathrm{C}_{i p s o},{ }^{t} \mathrm{BuN}\right), 106.7,109.0,110.2,113.0,115.5$, 118.6, $127.5\left(\mathrm{C}_{5} \mathrm{H}_{3}, \mathrm{C}_{5} \mathrm{H}_{4}\right), 110.6,132.9,137.9\left(\left(\mathrm{C}_{i p s o}\right.\right.$, $\left.\mathrm{C}_{5} \mathrm{H}_{4}, \mathrm{C}_{5} \mathrm{H}_{3}\right)$. MS (EI) $m / z: 585[\mathrm{M}]^{+}(2 \%) ; 570[\mathrm{M}-$ $\left.\mathrm{CH}_{3}\right]^{+}(100 \%) ; 513\left[\mathrm{M}-{ }^{t} \mathrm{Bu}-\mathrm{CH}_{3}\right]^{+}(18 \%) ; 392\left[\mathrm{M}-\mathrm{CH}_{3}\right.$ $\left.-1,3\left({ }^{t} \mathrm{Bu}\right)_{2} \mathrm{C}_{5} \mathrm{H}_{3}\right]^{+}(26 \%) ; 336\left[\mathrm{M}-1,3\left({ }^{t} \mathrm{Bu}\right)_{2} \mathrm{C}_{5} \mathrm{H}_{3}-\mathrm{CH}_{3}-\right.$ $\left.{ }^{t} \mathrm{Bu}\right]^{+}(65 \%)$.

\subsection{Crystal structure determination of $\mathrm{Hf}\left\{\left(\eta^{5}-\mathrm{C}_{5} \mathrm{H}_{4}\right) \mathrm{SiMe}_{2} \mathrm{OSiMe}_{2}\left(\eta^{5}-\mathrm{C}_{5} \mathrm{H}_{4}\right)\right\} \mathrm{Cl}_{2}$ (3c) and $\mathrm{Zr}\left(\mathrm{C}_{5} \mathrm{H}_{3}-1,3-{ }^{t} \mathrm{Bu} u_{2}\right)\left(\eta^{5}-\mathrm{C}_{5} \mathrm{H}_{4} \mathrm{SiMe}_{2}-\eta-\mathrm{N}^{t} \mathrm{Bu}\right) \mathrm{Cl}(\mathbf{8 b})$}

Crystals of the two compounds were obtained by crystallisation from toluene-hexane solutions. Suitable sized crystals of $\mathbf{3 c}$ and $\mathbf{8 b}$ were selected, sealed in Lindemann tubes under an argon atmosphere and mounted in an Enraf-Nonius CAD 4 automatic four- 
Table 4

Crystal, experimental data and structure refinement procedures for compounds $3 \mathbf{c}$ and $\mathbf{8 b}$

\begin{tabular}{|c|c|c|}
\hline & $3 c$ & $8 b$ \\
\hline Formula & $\mathrm{C}_{14}, \mathrm{H}_{20}, \mathrm{Cl}_{2}, \mathrm{O}, \mathrm{Hf}, \mathrm{Si}_{2}$ & $\mathrm{C}_{24}, \mathrm{H}_{40}, \mathrm{Cl}, \mathrm{N}, \mathrm{Si}, \mathrm{Zr}$ \\
\hline$M_{\mathrm{w}}$ & 509.87 & 497.33 \\
\hline Crystal habit & Prismatic & Prismatic \\
\hline Colour & White & White \\
\hline Crystal size (mm) & $0.25 \times 0.28 \times 0.30$ & $0.21 \times 0.25 \times 0.31$ \\
\hline Symmetry & $\begin{array}{l}\text { Monoclinic, } \\
P 2_{1} / c\end{array}$ & $\begin{array}{l}\text { Orthorombic, } \\
P 2_{1} 2_{1} 2_{1}\end{array}$ \\
\hline \multicolumn{3}{|l|}{ Unit cell dimensions } \\
\hline$a(\AA)$ & $13.482(8)$ & $8.703(3)$ \\
\hline$b(\AA)$ & $8.664(1)$ & $15.254(4)$ \\
\hline$c(\AA)$ & $15.38(2)$ & $19.226(7)$ \\
\hline$\beta\left({ }^{\circ}\right)$ & $97.26(3)$ & \\
\hline$V\left(\AA^{3}\right)$ & $1782(2)$ & $2552(1)$ \\
\hline$Z$ & 4 & 4 \\
\hline$D_{\text {calc }}\left(\mathrm{g} \mathrm{cm}^{-3}\right)$ & 1.900 & 1.294 \\
\hline$F(000)$ & 984 & 1048 \\
\hline$\mu\left(\mathrm{cm}^{-1}\right)$ & 62.81 & 5.92 \\
\hline Scan mode & $\begin{array}{l}\omega / 2 \theta \\
2.67<\theta<25.05\end{array}$ & $\begin{array}{l}\omega / 2 \theta \\
2.12<\theta<25.02\end{array}$ \\
\hline Reflections measured & 3328 & 2622 \\
\hline Independent reflections & 3145 & 2569 \\
\hline Reflections observed & $2814[I>2 \sigma(I)]$ & $2052[I>2 \sigma(I)]$ \\
\hline Range of $h k l$ & $\begin{array}{l}-16<h<15 \\
-3<k<10 \\
-3<l<18\end{array}$ & $\begin{array}{l}0<h<10 \\
-18<k<0 \\
0<l<22\end{array}$ \\
\hline Standard reflections & $\begin{array}{l}\text { Three every } 200 \\
\text { reflections }\end{array}$ & $\begin{array}{l}\text { Three every } 200 \\
\text { reflections }\end{array}$ \\
\hline Refinement method & \multicolumn{2}{|c|}{ Full-matrix least-squares on $F^{2}$} \\
\hline Final $R$ indices ${ }^{\text {a }}$ & $\begin{array}{l}R_{1}=0.0281 \\
w R_{2}=0.0716\end{array}$ & $\begin{array}{l}R_{1}=0.0348 \\
w R_{2}=0.0712\end{array}$ \\
\hline \multicolumn{3}{|l|}{$\begin{array}{l}\text { Weighting scheme } \\
\text { parameters }{ }^{b}\end{array}$} \\
\hline$x$ & 0.0448 & 0.0301 \\
\hline$y$ & 3.4441 & 0.9525 \\
\hline $\begin{array}{l}\text { Largest difference peak } \\
\text { and hole }\left(\mathrm{e} \AA^{-3}\right)\end{array}$ & $0.97 /-0.95$ & $0.4 /-0.39$ \\
\hline Goodness-of-fit on $F^{2}$ & 1.096 & 1.110 \\
\hline
\end{tabular}

${ }^{\text {a }} R_{1}=\Sigma|| F_{\mathrm{o}}|-| F_{\mathrm{c}}|| / \Sigma\left|F_{\mathrm{o}}\right| ; w R_{2}=\left\{\Sigma\left[\omega\left(\left(F_{\mathrm{o}}^{2}-F_{\mathrm{c}}^{2}\right)^{2}\right] / \Sigma\left[\omega\left(\mathrm{F}_{\mathrm{o}}^{2}\right)^{2}\right]\right\}^{1 / 2}\right.$.

${ }^{\mathrm{b}}$ Calc. $\omega=1 /\left[\sigma^{2}\left(F_{\mathrm{o}}^{2}\right)+(x P)^{2}+y P\right]$ where $P=\left(F_{\mathrm{o}}^{2}+2 F_{\mathrm{c}}^{2}\right) / 3$.

circle diffractometer with graphite monochromated Mo $-\mathrm{K}_{\alpha}$ radiation $(\lambda=0.71073 \AA)$. Crystallographic and experimental details for both structures are summarised in Table 4. Data were collected at r.t. Intensities were corrected for Lorentz and polarisation effects in the usual manner. No absorption or extinction corrections were made. The structures were solved by direct methods (SHELXL-90) [30] and refined by leastsquares against $F^{2}$ (SHELXL-93) [31]. All non-hydrogen atoms were refined anisotropically, and the hydrogen atoms were introduced from geometrical calculations and refined using a riding model with a thermal parameters equivalent to that of the carbon atom to which they were attached. Calculations were carried out on an ALPHA AXP (Digital) workstation.

\section{Supplementary material}

The final coordinates for the non-hydrogen atoms with the equivalent isotropic thermal parameters, $U_{\text {eq }}$, the coordinates for the hydrogen atoms with the isotropic thermal parameters, anisotropic thermal parameters for the non hydrogen atoms, and a complete list of bond distances, angles and observed and calculated structure factors have been deposited for both structures with the Cambridge Crystallographic Data Centre as a supplementary publication, CCDC nos. 139588 for $\mathbf{3 c}$ and 139589 for $\mathbf{8 b}$. Copies of this information may be obtained free of charge from The Director, CCDC, 12 Union Road, Cambridge CB2 1EZ, UK (fax: +44-1223-336033; e-mail: deposit@ccdc.cam.ac.uk or www: http://www.ccdc. cam.ac.uk).

\section{Acknowledgements}

Financial support for this research by DGICYT (Project PB97-0776) is gratefully acknowledged.

\section{References}

[1] (a) S.G. Davies, Organotransition Metal Chemistry: Applications to Organic Synthesis, Pergamon, Oxford, 1989. (b) E.W. Abel, F.G.A. Stone, G. Wilkinson (Eds.), Comprehensive Organometallic Chemistry II. A Review of the Literature (19821994), vol. 4, 1994. (c) F.A. Cotton, G. Wilkinson, C.A. Murillo, M. Bochmann, Advanced Inorganic Chemistry, sixth ed., Wiley, New York, 1999.

[2] (a) W. Kaminsky, H. Sinn (Eds.), Transition Metals and Organometallics as Catalysts for Olefin Polymerization, Springer, New York, 1988. (b) R.F. Jordan, Adv. Organomet. Chem. 32 (1991) 3235. (c) H.H. Brintzinger, D. Fischer, R. Mülhaupt, B. Rieger, R.M. Waymouth, Angew. Chem. Int. Ed. Engl. 34 (1995) 1143. (d) M. Bochmann, J. Chem. Soc. Dalton Trans. (1996) 225.

[3] (a) J. Okuda, Comm. Inorg. Chem. 16 (1994) 185. (b) P.C. Möhring, N.J. Coville, J. Organomet. Chem. 479 (1994) 1. (c) P. Jutzi, U. Siemeling, J. Organomet. Chem. 500 (1995) 175 and references therein. (c) V. Varga, J. Hiller, R. Gyepes, M. Polásek, P. Sedmera, U. Thewalt, K. Mach, J. Organomet. Chem. 538 (1997) 63.

[4] (a) P.J. Shapiro, E. Bunel, W.P. Schaefer, J.E. Bercaw, Organometallics 9 (1990) 867. (b) P.J. Shapiro, W.D. Cotter, W.P. Schaefer, J.A. Labinger, J.E. Bercaw, J. Am. Chem. Soc. 116 (1994) 4623. (c) U. Böhme, K.H. Thiele, J. Organomet. Chem. 472 (1994) 39. (d) J. Okuda, F.J. Schattenmann, S. Wocadlo, W. Massa, Organometallics 14 (1995) 789. (e) K.E.D. Plooy, U. Moll, S. Wocadlo, W. Massa, J. Okuda, Organometallics 14 (1995) 3129. (f) R.E.v.H. Spence, W.E. Piers, Organometallics 14 (1995) 4617. (g) W.A. Herrmann, M.J.A. Morawietz, T. Priermeier, Angew. Chem. Int. Ed. Eng. 33 (1994) 1946. (h) W.A. Herrmann, M.J.A. Morawietz, T. Priermeier, K. Mashima, J. Organomet. Chem. 486 (1995) 291. (i) M.S. Blais, J.C.W. Chien, M.D. Rausch, Organometallics 17 (1998) 3775. (j) J. Okuda, T. Eberle, T.P. Spaniol, V. Piquet-Fauré, J. Organomet. Chem. 591 (1999) 127. 
[5] (a) G. Erker, U. Korek, Z. Naturforsch. B Chem. Sci. 44 (1989) 1593. (b) R. Fandos, A. Meetsma, J.H. Teuben, Organometallics 10 (1991) 59. (c) R. Fandos, A. Meetsma, J.H. Teuben, Organometallics 10 (1991) 2665. (d) Y. Qiann, J. Huang, X. Chen, G. Li, W. Chen, B. Li, X. Jin, Q. Yang, Polyhedron 13. (1994) 1105. (e) G. Trouvé, D.A. Laske, A. Meetsma, J.H. Teuben, J. Organomet. Chem. 511 (1996) 255.

[6] (a) M. Ogasa, D.T. Mallin, D.W. Macomber, M.D. Rausch, R.D. Rogers, A.N. Rollins, J. Organomet. Chem. 405 (1991) 41. (b) G. Erker, S. Wilker, C. Krüger, M. Nolte, Organometallics 12 (1993) 2140. (c) Z. Wu, R.F. Jordan, J. Am. Chem. Soc. 117 (1995) 5867. (d) J. Okuda, K.E. du Plooy, P.J. Toscano, J. Organomet. Chem. 495 (1995) 195. (e) M.V. Galakhov, G. Heinz, P. Royo, J. Chem. Soc. Chem. Commun. (1998) 17.

[7] A.L. McKnight, R.M. Waymouth, Chem. Rev. 98 (1998) 2587.

[8] (a) J.C. Stevens, F.J. Timmers, D.R. Wilson, G.F. Schmidt, P.N. Nickias, R.K. Rose, G.W. Kinight, S. Lai, Eur. Pat. Appl. EP-416-815-A2 (1991). (b) J.M. Canich, Eur. Pat. Appl. EP-420436-A1 (1991). (c) J.M. Canich, G.G. Hlatky, H.W. Turner, US Pat. Appl. (1990) 542.

[9] (a) S. Ciruelos, T. Cuenca, P. Gómez-Sal, A. Manzanero, P. Royo, Organometallics 14 (1995) 177. (b) S. Ciruelos, T. Cuenca, R. Gómez, P. Gómez-Sal, A. Manzanero, P. Royo, Polyhedron 17 (1997) 1055.

[10] S. Ciruelos, T. Cuenca, R. Gómez, P. Gómez-Sal, A. Manzanero, P. Royo, Organometallics 15 (1996) 5577.

[11] T. Cuenca, P. Royo, Coord. Chem. Rev. 193-195 (1999) 447.

[12] (a) A.K. Hughes, A. Meetsma, J.H. Teuben, Organometallics 12 (1993) 1936. (b) W.A. Herrmann, M.J.A. Morawietz, J. Organomet. Chem. 482 (1994) 169.

[13] (a) G.H. Llinas, M. Mena, F. Palacios, P. Royo, R. Serrano, J. Organomet. Chem. 340 (1988) 37. (b) C.H. Winter, X.X. Zhou, D.A. Dobss, M. J. Heeg, Organometallics 10 (1991) 210.

[14] M.D. Curtis, J.J. D’Errico, D.N. Duffy, P.S. Epstein, L.G. Bell, Organometallics 2 (1983) 1808.

[15] (a) T. Cuenca, J.C. Flores, R. Gómez, P. Gómez-Sal, M ParraHake, P. Royo, Inorg. Chem. 32 (1993) 3608. (b) D.H. Lee, K.B Yoon, E.H. Lee, S.K. Noh, G.G. Buyn, C.S. Lee, Macromol. Rapid Commun. 16 (1995) 265. (c) J.L. Huhmann, J.Y. Corey, N.P. Rath, N.P.J. Organomet. Chem. 533 (1997) 61.

[16] C. Glidewel, D.W.H. Rankin, A.G. Robiete, G.M. Sheldrich, J. Chem. Soc. A (1970) 318.

[17] (a) C.H. Saldariaga-Molina, A. Clearfield, I. Bernal, Inorg. Chem. 13 (1974) 2880. (b) H.G. Alt, M. Jung, W. Milius, J. Organomet. Chem. 558 (1998) 111. (c) F. Amor, K.E. du Plooy,
T.P. Spaniol, J. Okuda, J. Organomet. Chem. 558 (1998) 139 and references cited therein. (d) S. Back, G. Rheinwald, L. Zsolnai, G. Huttner, H. Lang, J. Organomet. Chem. 563 (1998) 73 and references cited therein.

[18] (a) R.D. Rogers, M.M. Benning, L.K. Kurihara, K.J. Moriarty, M.D. Rausch, M.D. J. Organomet. Chem. 293 (1985) 51.(b) M. Osaga, D.T. Mallin, D.W. Macomber, M.D. Rausch, R.D. Rogers, A.N. Rollins, J. Organomet. Chem. 405 (1991) 41

[19] H.G. Alt, K. Föttinger, W. Milius, J. Organomet. Chem. 564 (1998) 109.

[20] (a) A.H. Thiele, U. Böhme, K. Peters, E.M. Peters, I. Walz, H.G. Schvering, Z. Anorg. Allg. Chem. 619 (1993) 771. (b) H. Sitzmann, P. Zhou, G. Wolmershäuser, Chem. Ver. 127 (1994) 3. (c) M.A. Schmid, H.G. Alt, W.J. Milius, J. Organomet. Chem. 514 (1996) 45. (d) R.D. Rogers, M.M. Bennig, L.K. Kurihara, K.J. Moriarty, M.D. Rauch, J. Organomet. Chem. 293 (1985) 51. (e) Y. Dusausoy, J. Protas, P. Renaut, B. Gautheron, G. Tainturier, J. Organomet. Chem. 157 (1978) 167. (f) I.A. Ronova, N.V. Alekseev, Zh. Strukt. Khim. 18 (1997) 212.

[21] (a) K. Prout, T.S. Cameron, R.A. Forder, S.R. Critchley, B. Denton, G.V. Rees, Acta Crystallogr. Sect. B 30 (1974) 2290. (b) E.L. Lyszak, J.P. O'Brien, D.A. Kort, S.K. Hendges, R.N. Redding, T.L. Busch, M.S. Hermen, K.B. Renkema, M.E. Silver, J.C. Huffman, Organometallics 12 (1993) 338.

[22] (a) D.W. Carpenetti, L. Kloppenburg, J.T. Kupec, J.L. Petersen, Organometallics 25 (1996) 1572. (b) Y. Mu, W.E. Piers, D.C. MacQuarrie, M.J. Zaworotko, Can. J. Chem. 74 (1991) 1696.

[23] M.A. Giardello, M.S. Eisen, C.L. Stern, T.J. Marks, J. Am. Chem. Soc. 117 (1995) 12114.

[24] (a) M.F. Lappert, P.B. Power, A.R. Sanger, R.C. Srivastava, Metal and Metalloid Amines, Ellis Horwood, Chichester, West Sussex, UK, 1980. (b) R.V. Bynum, W.E. Hunter, R.D. Rogers, J.L. Atwood, Inorg. Chem. 19 (1980) 2368.

[25] (a) P.R. Jones, J.M. Rozell, B.M. Campbell, Organometallics 4 (1985) 1321. (b). M. Rozell, P.R. Jones, J. Organomet. 4 (1985) 2206.

[26] J. Hiermeier, F.H. Köhler, G. Müller, Organometallics 10 (1991) 1787.

[27] C.V. Vernier, E.W. Casserly, J. Am. Chem. Soc. 112 (1990) 2808.

[28] H. Werner, M. Otto, H.J. Kraus, J. Organomet. Chem. 328 (1986) C1.

[29] M. Mena, Doctoral Thesis, University of Alcalá, Spain, 1988.

[30] G.M. Sheldrick, Acta Crystallogr. 46 (1990) 467.

[31] G.M. Sheldrick, SHELXL 93, University of Göttingen, Germany, 1993. 